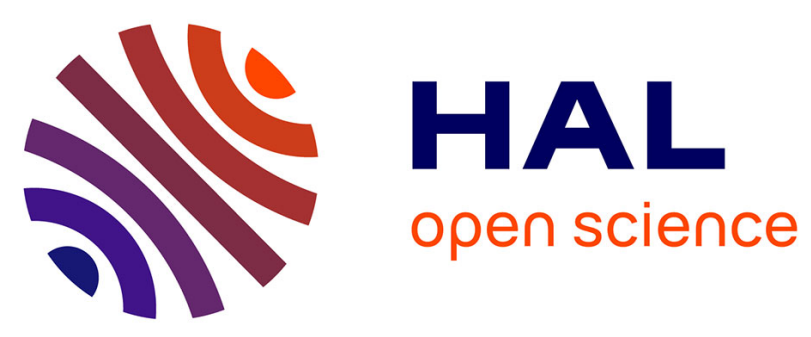

\title{
Detrital zircon provenance comparison between the Paleocene-Eocene Nangqian-Xialaxiu and Gongjue basins: New insights for Cenozoic paleogeographic evolution of the eastern Tibetan Plateau
}

Yang Zhang, Wentao Huang, Yuanyuan Zhang, Marc Poujol, Stephane Guillot, Pierrick Roperch, Guillaume Dupont-Nivet, Zhaojie Guo

\section{To cite this version:}

Yang Zhang, Wentao Huang, Yuanyuan Zhang, Marc Poujol, Stephane Guillot, et al.. Detrital zircon provenance comparison between the Paleocene-Eocene Nangqian-Xialaxiu and Gongjue basins: New insights for Cenozoic paleogeographic evolution of the eastern Tibetan Plateau. Palaeogeography, Palaeoclimatology, Palaeoecology, 2019, 533 (109241), 10.1016/j.palaeo.2019.109241 . insu-02163742

\section{HAL Id: insu-02163742 \\ https://hal-insu.archives-ouvertes.fr/insu-02163742}

Submitted on 24 Jun 2019

HAL is a multi-disciplinary open access archive for the deposit and dissemination of scientific research documents, whether they are published or not. The documents may come from teaching and research institutions in France or abroad, or from public or private research centers.
L'archive ouverte pluridisciplinaire HAL, est destinée au dépôt et à la diffusion de documents scientifiques de niveau recherche, publiés ou non, émanant des établissements d'enseignement et de recherche français ou étrangers, des laboratoires publics ou privés. 


\section{Accepted Manuscript}

Detrital zircon provenance comparison between the PaleoceneEocene Nangqian-Xialaxiu and Gongjue basins: New insights for Cenozoic paleogeographic evolution of the eastern Tibetan Plateau

Yang Zhang, Wentao Huang, Yuanyuan Zhang, Marc Poujol, Stéphane Guillot, Pierrick Roperch, Guillaume Dupont-Nivet,

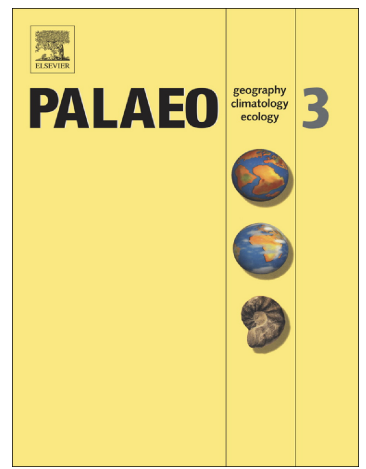
Zhaojie Guo

PII:

S0031-0182(19)30294-9

DOI: https://doi.org/10.1016/j.palaeo.2019.109241

Article Number: 109241

Reference: PALAEO 109241

To appear in: Palaeogeography, Palaeoclimatology, Palaeoecology

Received date: 29 March 2019

Revised date: 12 June 2019

Accepted date: 12 June 2019

Please cite this article as: Y. Zhang, W. Huang, Y. Zhang, et al., Detrital zircon provenance comparison between the Paleocene-Eocene Nangqian-Xialaxiu and Gongjue basins: New insights for Cenozoic paleogeographic evolution of the eastern Tibetan Plateau, Palaeogeography, Palaeoclimatology, Palaeoecology, https://doi.org/10.1016/ j.palaeo.2019.109241

This is a PDF file of an unedited manuscript that has been accepted for publication. As a service to our customers we are providing this early version of the manuscript. The manuscript will undergo copyediting, typesetting, and review of the resulting proof before it is published in its final form. Please note that during the production process errors may be discovered which could affect the content, and all legal disclaimers that apply to the journal pertain. 


\section{Detrital zircon provenance comparison between the Paleocene-Eocene}

Nangqian-Xialaxiu and Gongjue basins: new insights for Cenozoic

$$
\text { paleogeographic evolution of the eastern Tibetan Plateau }
$$

Yang Zhang ${ }^{1}$, Wentao Huang ${ }^{2}$, Yuanyuan Zhang ${ }^{1}$, Marc Poujol ${ }^{3}$, Stéphane Guillot ${ }^{4}$, Pierrick

$$
\text { Roperch }^{3} \text {, Guillaume Dupont-Nivet }{ }^{1,3,5} \text {, and Zhaojie Guo }{ }^{1}
$$

${ }^{1}$ Key Laboratory of Orogenic Belts and Crustal Evolution, Ministry of Education, School of Earth and Space Sciences, Peking University, Beijing 100871, China

${ }^{2}$ Department of Earth and Environmental Sciences, University of Rochester, Rochester, New York 14627, USA

${ }^{3}$ Univ. Rennes, CNRS, Géosciences Rennes-UMR 6118, F-35000 Rennes, France

${ }^{4}$ University of Grenoble Alpes, CNRS, IRD, IFSTTAR, ISTerre, 38000 Grenoble, France

${ }^{5}$ Institute of Earth and Environmental Sciences, University of Potsdam, Potsdam, Golm 14476, Germany

\section{Abstract}

Paleogeographic reconstructions of terranes can greatly benefit from the provenance analysis of sediments. A series of Cenozoic basins provide key sedimentary archives for investigating the growth of the Tibetan Plateau, yet the provenance of the sediments in these basins has never been constrained robustly. Here we report sedimentary petrological and detrital zircon geochronological data from the Paleocene-Eocene Nangqian-Xialaxiu and Gongjue basins. Sandstone detrital modes and zircon morphology suggest that the samples collected in these two basins were sourced from recycled orogen. Detrital zircon geochronology indicates that sediments 
in the Nangqian-Xialaxiu Basin are characterized by two distinct age populations at 220-280 Ma and 405-445 Ma. In contrast, three predominant age populations of 207-256 Ma, 423-445 Ma, and 1851-1868 Ma, and two subordinate age populations of $\sim 50 \mathrm{Ma}$ and $\sim 2500 \mathrm{Ma}$, are recognized in the Gongjue Basin. Comparison with detrital zircon ages from the surrounding terranes suggests that sediments in the Nangqian-Xialaxiu Basin come from the neighboring thrust belts, whereas sediments from the Gongjue Basin are predominantly derived from the distant Songpan-Ganzi Terrane with minor contribution from the surrounding areas. A three-stage Cenozoic evolution of the eastern Tibetan Plateau is proposed. During the Paleocene, the Nangqian-Xialaxiu Basin appeared as a set of small intermontane sub-basins and received plentiful sediments from the neighboring mountain belts; during the Eocene, the Gongjue Basin kept a relatively low altitude and was a depression at the edge of a proto-Plateau; since the Oligocene, the Tibetan Plateau further uplifted and the marginal Gongjue Basin was involved in the Tibetan interior orogeny, indicating the eastward propagation of the Tibetan Plateau.

Key words: U-Pb geochronology; sandstone detrital modes; Cenozoic basins; tectonic reconstruction; eastern Tibetan Plateau.

\section{Introduction}

To understand the growth and uplift of the Tibetan Plateau, the study of the basin development, sedimentary provenance, and depositional processes are crucial (e.g., Fielding, 1996; Clark et al., 2005; Zhu et al., 2006b; Li et al., 2012; Yuan et al., 2013; Zhang et al., 2013; Zhang et al., 2014). Previous geological investigations of the 
sedimentary records within and along the periphery of the Tibetan Plateau have significantly improved our understanding of the terrane accretion and associated tectonic deformation and uplift since the Paleozoic (e.g., Wang et al., 2001a; Otofuji et al., 2007; Pullen et al., 2008; Li et al., 2009; Dupont-Nivet et al., 2010; Zhai et al., 2011a; Kornfeld et al., 2014; Ma et al., 2014; Yu et al., 2014, 2017; Huang et al., 2015; Tong et al., 2015; Li et al., 2017, 2018b; McRivette et al., 2019; Wu et al., 2019a, 2019b). The India-Asia collision in the early Paleogene and the subsequent continental deformation are thought to have induced most of the plateau growth as expressed by the development of a series of foreland basins within and in the periphery of the Himalayan-Tibetan orogen (e.g., Allégre et al., 1984; Yin and Harrison, 2000; Najman, 2005; Wu et al., 2010; DeCelles et al., 2014). In particular, the Cenozoic sedimentary basins in the eastern Qiangtang Terrane (east-central interior of the Tibetan Plateau) provide an excellent record of the early collision history during the Paleogene (e.g., Horton et al., 2002). The geological framework of these Cenozoic basins (e.g., the Nangqian-Xialaxiu and Gongjue basins studied here) has been established (e.g., Horton et al., 2002; Spurlin et al., 2005; Studnicki-Gizbert et al., 2008) based on structural geology, stratigraphy, and isotopic dating of the exposed volcanic rocks (e.g., Zhou et al., 2002; Zhu et al., 2006a; Jiang et al., 2009; Du et al., 2011a). Recently, stable isotope paleoaltimetry has constrained the late Eocene paleoelevation of the Nangqian-Xialaxiu and the early Eocene paleoelevation of the Gongjue basins to $3.0 \pm 1.1 \mathrm{~km}$ and $2.1-2.5 \mathrm{~km}$, respectively (Tang et al., 2017; Li et al., 2018a). Moreover, paleomagnetic studies on the Nangqian-Xialaxiu and 
Gongjue basins indicate significant early Eocene latitudinal crustal shortening and variable clockwise rotation (Roperch et al., 2017; Tong et al., 2017; Zhang et al., 2018), suggesting that crustal shortening and oroclinal bending or lateral extrusion are the main mechanisms for accommodating the convergence. Despite of these substantial progresses, the provenances of the sediments in these two Cenozoic basins in the eastern Tibetan Plateau, as well as the relationships between drainage basins and their source regions, remain poorly constrained.

Sandstone detrital modes and detrital zircon U-Pb geochronology are extremely powerful tools to constrain the provenance of terrigenous sediments, the evolution of sedimentary basins, and the tectonic affinity of the different blocks involved (e.g., Dickinson and Suczek, 1979; Dickinson et al., 1983; Gehrels et al., 2003; Weislogel et al., 2006, 2010; Enkelmann et al., 2007; Dong et al., 2011; Zhu et al., 2011a; Dai et al., 2012; Fan et al., 2015; Li et al., 2015a; Wang et al., 2017). Nevertheless, these tools have not been applied for regional provenance analyses of the Paleogene Nangqian-Xialaxiu and Gongjue basins, although potential source areas are suggested to be the Songpan-Ganzi Terrane to the north (e.g., Bruguier et al., 1997; Ding et al., 2013; Zhang et al., 2014), or the Yidun Block to the southeast (e.g., Wang et al., 2013; Peng et al., 2014; Wu et al., 2016). Therefore, the aim of this paper is to determine the potential source areas of these sediments preserved in the Paleocene-Eocene Nangqian-Xialaxiu Basin and the Gongjue Basin in the eastern Qiangtang Terrane by examining their petrographic characteristics and detrital zircon $\mathrm{U}-\mathrm{Pb}$ age distributions. By comparing the evolution of the source areas of these two basins, we tentatively 
provide constraints on the regional tectonic evolution of the eastern Tibetan Plateau at its early stage of growth.

\section{Geological setting and sampling}

The Qiangtang Terrane is one of the principal Gondwana-derived units that constitute the crust of central Tibet (Figure 1a) (Kapp et al., 2000, 2003a, 2003b; Metcalfe, 2013). It is bounded by the Jinsha suture to the north, which represents the Late Triassic collision with the Songpan-Ganzi Terrane. To the south, it is restricted by the Bangong-Nujiang suture, recording the Late Jurassic-Early Cretaceous collision with the Lhasa Terrane (Figure 1a) (e.g., Sengör and Natalin, 1996; Yin and Harrison, 2000; Yang et al., 2012). It is approximately east-west-trending in the western and central parts with a maximum width of 400-500 km, but narrows down to less than $150 \mathrm{~km}$ in the eastern part and changes gradually from NW-SE trending in the southeast of Tibet to an approximate south-north trending in the Yunnan Province. The Qiangtang Terrane can be further divided into the eastern and western Qiangtang sub-Terranes through the Longmo Co-Shuanghu-Lancangjiang suture (LSLS) (Figure 1a) (e.g., Zhang et al., 2006a, b; Li et al., 2009). However, this east-west belt of ophiolitic melanges is also interpreted to be the remnants of a subduction-accretion complex instead of a Mesozoic suture zone or remnants of a large ophiolite nappe (Kapp et al., 2003a, 2003b). The western Qiangtang Terrane began to collide with the eastern Qiangtang Terrane during the middle Triassic, forming the so-called Qiangtang Terrane (e.g., Zhang et al., 2006a, b; Li et al., 2009; Zhai et al., 2011; Metcalfe, 2013). During the initial stage of the India-Asia collision, substantial 
deformation is characterized by important crustal shortening, mainly north-dipping thrust systems, and strike-slip faults along these suture zones (Kapp et al., 2005; Staisch et al., 2016). During this time, sediment accumulations are preserved in the northeastern part of the Qiangtang Terrane in a series of small thrust-related Cenozoic basins (Horton et al., 2002; Studnicki-Gizbert et al., 2008), providing key records for unraveling the Cenozoic tectonic evolution of the eastern Tibetan Plateau.

\subsection{The Nangqian-Xialaxiu Basin}

The Nangqian-Xialaxiu Basin is one of the largest and most complete Cenozoic basins related to the India-Asia collision in the eastern Tibetan Plateau. It covers more than $1800 \mathrm{~km}^{2}$ with strata thickness ranging from $\sim 3200 \mathrm{~m}$ in the north to $\sim 4400 \mathrm{~m}$ in the south (Figures 1b, 2a) (Qinghai BGMR, 1991). Development of the Nangqian-Xialaxiu Basin is probably controlled by the Cenozoic Nangqian Thrust System, which cuts across the northern part of the Qiangtang Terrane. This basin can be divided into four distinctive sub-basins (the Shanglaxiu, Xialaxiu, Niuguoda, and Nangqian basins) separated by thrust faults (Horton et al., 2002). These northeast- and southwest-directed principal structural thrusts were responsible for a minimum of 61 $\mathrm{km}$ of Cenozoic SW-NE shortening and for the juxtaposition of Paleozoic-Mesozoic strata over Cenozoic strata in the study region (Spurlin et al., 2005). The basin is filled with Cretaceous-Paleogene strata, mainly consisting of sandstone, mudstone, conglomerate, and minor carbonate and volcanic rocks (Horton et al., 2002; Spurlin et al., 2005). The Cenozoic strata unconformably overlie the Carboniferous and Triassic strata but are in conformable contact with the underlying upper Cretaceous strata. The 
Paleozoic and Mesozoic strata are dominantly composed of carbonate, quartzite, argillite, sandstone, and mudstone. Palynomorph and ostracod assemblages discovered in the lowermost succession of the Nangqian area yield a late Cretaceous age (Qinghai BGMR, 1991). Other sub-basins and major strata in the Nangqian area are also Paleocene-Eocene deposition (Qinghai BGMR, 1991; Horton et al., 2002). Geochronological studies performed on rhyolite and granitic intrusives in the Xialaxiu area yield ${ }^{40} \mathrm{Ar} /{ }^{39} \mathrm{Ar}$ ages of 51.2-49.5 Ma (Spurlin et al., 2005). Furthermore, tuffs in the uppermost strata of the northern Nangqian area yield ${ }^{40} \mathrm{Ar} /{ }^{39} \mathrm{Ar}$ ages of 38.2-37.2 Ma (Spurlin et al., 2005), while zircon U-Pb dating reveals that the Nangqian igneous rocks formed at 39.5-35.6 $\mathrm{Ma}$ (Xu et al., 2016). These ages provide minimum age constraints for the basin infill.

\subsection{The Gongjue Basin}

The Gongjue Basin is located to the southeast of the Nangqian-Xialaxiu Basin. It extends for $\sim 200 \mathrm{~km}$ in a NW-SE trend along the eastern side of the Qiangtang Terrane (Figure 1). The sedimentary strata mainly consist of the Gongjue Formation in the lower and Ranmugou Formation in the upper part of the basin with a total thickness up to $\sim 5000 \mathrm{~m}$ (Figure 2b) (Tibet BGMR, 1993). The basin fill is dominated by terrestrial red clastic sediments (fine, coarse, sand-, silt-, or mud-sized sediments) and evaporites (gypsum, salt, and carbonates), displaying parallel bedding, cross bedding, graded bedding, erosional surfaces, and ripple marks (Figure 4). It is interpreted as an internally drained, structurally controlled basin which has predominantly been deposited in an alluvial-fan, fan-delta, floodplain, and lacustrine 
environment (Tibet BGMR, 1993). The structure of the Gongjue Basin is characterized by a southwest-directed thrust and a basin-scale asymmetrical syncline with a better exposed and thicker western limb than that of the eastern limb (Figure $2 \mathrm{~b}$ ). These fold axes are also parallel to the strike of the bedding and the overall orientation of the basin (Figures 1b, 2b). On the eastern side, the middle-upper Triassic marine limestones cut and thrust upon the basin sediments; on the western side, the Cenozoic sediments unconformably overlie the Ordovician to Triassic strata of the Qiangtang Terrane. Initial growth strata developed along both the eastern and western sides of the basin and small-scale folds are well preserved in the upper part of the strata near the core of the syncline (Tibet BGMR, 1993; Studnicki-Gizbert et al., 2008). Palynology assemblages from the basin sedimentary sequence give a Cenozoic age from early Paleogene to Miocene (Tibet BGMR, 1993; Studnicki-Gizbert et al., 2008). Precise geochronology of the youngest zircon cluster collected from the Gongjue Formation red beds yields a weighted mean age of $52.5 \pm 1.5 \mathrm{Ma}$, providing a maximum depositional age for this basin (Zhang et al., 2018). Volcanic rocks with

eruption age of $43.83 \pm 0.27 \mathrm{Ma}$ (biotite ${ }^{40} \mathrm{Ar} /{ }^{39} \mathrm{Ar}$ ) and $43.2 \pm 0.2 \mathrm{Ma}$ (zircon $\mathrm{U}-\mathrm{Pb}$ ) in the northern part of the basin also provide a minimum depositional age constraint for these red beds strata (Studnicki-Gizbert et al., 2008; Tang et al., 2017).

\subsection{Sampling}

In the Nangqian-Xialaxiu Basin, five fine- and coarse-grain sized sandstone samples from Nangqian section and four from Xialaxiu section were collected in the field and studied under a petrological microscope (Figures 3, 4j-m, 5; Table $S 2$ in the 
supplementary material). In the Gongjue Basin, nine fine- and medium-grained sandstone samples from the Qinidong section and eight from the Xiangpi section were collected for microscopic studies (Figures 3, 4e-i, 5; Table S2 in the supplementary material).

Additionally, in this study, three samples from the Nangqian-Xialaxiu Basin, including a Middle Eocene sample NQ14-01, an Early Eocene sample NQ14-02, and a Paleocene sample XL14-02, were collected for detrital zircon U-Pb geochronology. In the Gongjue Basin, five Early Eocene samples encompassing the entire stratigraphy were selected for detrital zircon U-Pb geochronology, of which samples GJ-7 and GJ-24 are from the Gongjue Formation in the lower part, sample JD-8 belongs to the Lower Ranmugou Formation, and samples JD-14 and JD-21 are from the Middle Ranmugou Formation in the upper part of the basin. Sampling localities and brief petrological characteristics are presented in the supplementary material Table S1 and Figure 2.

\section{Methods}

\subsection{Sandstone detrital modes}

Sandstone detrital modes of terrigenous sandstones from various types of basin are closely connected with the plate-tectonic setting of the source area (Dickinson and Suczek, 1979; Dickinson et al., 1983). The categories of provenance terranes are divided into three main units: "recycled orogens", "continental blocks", and "magmatic arcs" (Figure 5) (Dickinson et al., 1983). By measuring the point counts in thin sections, the application of this method to successfully judge the sandstone 
provenance has been well established (e.g., Dickinson and Suczek, 1979; Dickinson, 1985). More than 400 mineral grains were counted for each sample following the Gazzi-Dickinson method (Ingersoll et al., 1984). Sandstone compositions can then be plotted into triangular QtFL and QmFLt diagrams which represent the framework proportions of quartz, feldspar, and lithic debris made of polycrystalline quartz, as well as constituents with a volcanic and/or sedimentary origin. Framework grain types, size limit $(>62.5 \mu \mathrm{m})$, and graphical representations of the quantitative detrital modes and various provenance fields are from Dickinson et al. (1983). The grain compositional abundances, normalized to $100 \%$, are shown in Table S2 in the supplementary material.

\subsection{Detrital zircon U-Pb dating}

Zircon grains were concentrated using conventional heavy liquid and magnetic techniques at the Yuneng Geology Service Co. Ltd., Langfang, Hebei Province, China. Generally, more than 1000 zircon grains were randomly selected to be mounted in epoxy mounts, and then polished in order to obtain a smooth flat internal surface. In order to inspect the internal structure and choose the potential internal target sites for the U-Pb laser ablation-inductively coupled plasma-mass spectrometry (LA-ICP-MS) dating, transmitted and reflected light microscopy, as well as cathodoluminescence (CL) imagery were acquired. Zircon grains from the Nangqian-Xialaxiu Basin were analyzed at the Geosciences Rennes laboratory (France), while zircon grains from the Gongjue Basin were measured at the Key Laboratory of Orogenic Belts and Crustal Evolution (Peking University, China). 
For the samples analyzed in Rennes, U-Pb geochronology was conducted using an ESI NWR193UC Excimer laser coupled to a quadripole Agilent 7700x ICP-MS. The instrumental conditions are reported in Table S3 in the supplementary material. The ablated material is carried into helium, and then mixed with nitrogen and argon, before injection into the plasma source. The alignment of the instrument and mass calibration was performed before each analytical session using the NIST SRM 612 reference glass, by inspecting the ${ }^{238} \mathrm{U}$ signal and by minimizing the $\mathrm{ThO}^{+} / \mathrm{Th}^{+}$ratio $(<0.5 \%)$. During the course of an analysis, the signals of ${ }^{204}(\mathrm{~Pb}+\mathrm{Hg}),{ }^{206} \mathrm{~Pb},{ }^{207} \mathrm{~Pb}$, ${ }^{208} \mathrm{~Pb},{ }^{232} \mathrm{Th}$ and ${ }^{238} \mathrm{U}$ masses are acquired. The occurrence of common $\mathrm{Pb}$ in the sample can be monitored by the evolution of the ${ }^{204}(\mathrm{~Pb}+\mathrm{Hg})$ signal intensity, but no common $\mathrm{Pb}$ correction was applied owing to the large isobaric interference with $\mathrm{Hg}$. Single analyses consisted of $20 \mathrm{~s}$ of background integration followed by $60 \mathrm{~s}$ integration with the laser firing. Ablation spot diameters of $20-45 \mu \mathrm{m}$ with repetition rates of $3 \mathrm{~Hz}$ were used depending on the grain size. Data were corrected for $\mathrm{U}-\mathrm{Pb}$ and $\mathrm{Th}-\mathrm{Pb}$ fractionation and for the mass bias by standard bracketing with repeated measurements of the GJ-1 zircon standard (Jackson et al., 2004). Along with the unknowns, zircon standards Plešovice (337 Ma, Sláma et al., 2008) and 91500 (1065 Ma, Wiedenbeck et al., 1995) were measured to monitor precision and accuracy of the analyses and produced a concordia age of $336.6 \pm 4.7 \mathrm{Ma}(\mathrm{N}=86, \mathrm{MSWD}=0.05)$ and $1066.5 \pm 1.8 \mathrm{Ma}(\mathrm{N}=93, \mathrm{MSWD}=0.16)$ respectively during the course of the analyses. See Manzotti et al. (2015) for further information.

For samples analyzed in Peking University, U-Pb geochronology was conducted 
on an Agilent 7500 Ce ICP-MS connected to a $193 \mathrm{~nm}$ COMPexPro 102 Excimer Laser ablation system. The instrumental conditions are reported in Table S3 in the supplementary material. Helium gas was used as the carrier gas to enhance the transport efficiency of the ablated material. The laser spot diameter was $32 \mu \mathrm{m}$, and the laser energy density was $6 \mathrm{~J} / \mathrm{cm}^{2}$ with the frequency set to $5 \mathrm{~Hz}$. The procedure for laser analysis involved a 20-pulse pre-denudation, $25 \mathrm{~s}$ of blank calibration, $60 \mathrm{~s}$ of signal acquisition, and 2 min of sample-chamber flushing after ablation. Zircon standard 91500 (Wiedenbeck et al., 1995) was used as the primary standard and zircon Plešovice (337.9 Ma) as a secondary (quality control) standard (Sláma et al., 2008). The correction for common $\mathrm{Pb}$ is applied using the EXCEL program ComPbCorr\#_151 (Andersen, 2002). More detailed descriptions of the technical procedure are presented in Tang et al. (2014) and Yuan et al. (2004).

In both laboratories, the GLITTER 4.4.2 software (Macquarie University) was used to calculate the isotopic ratios and element concentrations. ISOPLOT (version 3.0) was used to create the relative probability and concordia diagrams (Ludwig, 2003). Reported uncertainties in age analyses are given at $1 \sigma$. Ages older than ca. $1000 \mathrm{Ma}$ are based on ${ }^{207} \mathrm{~Pb} /{ }^{206} \mathrm{~Pb}$ ratios, whereas younger grains are based on ${ }^{206} \mathrm{~Pb} /{ }^{238} \mathrm{U}$ ratios. Zircon $\mathrm{U}-\mathrm{Pb}$ ages with degrees of discordance $>10 \%$ were not taken into account for the age calculations. Isotopic ages with errors are listed in Table S4 in the supplementary material. CL images of representative zircon grains are presented in Figure 6.

\section{Analytical results}




\subsection{Petrology}

Sandstone samples from the Nangqian-Xialaxiu Basin are mainly fine- and medium-grained quartz greywackes which consist mostly of sub-angular to sub-rounded monocrystalline quartz grains. The other framework grains are principally composed of lithic fragments, which mainly include volcanic clasts, together with subordinate sedimentary clasts and polycrystalline quartz grains. Volcanic clasts display a cryptocrystalline texture, and mainly consist of volcanic glass and microlite, indicative of a rapid cooling of the magma (e.g., Figures $4 \mathrm{j}, 1$ ). Very few yellow metamorphic clasts were also found, probably linked to low-grade metamorphism of sedimentary clasts, which is certified by brittle deformation of quartzose crack (e.g., Figure 4l). Calcite is present in most of the samples (e.g., Figure $4 \mathrm{k})$.

Most sandstone samples from the Gongjue Basin contain similar components and consist dominantly of texturally mature monocrystalline/polycrystalline quartz and lithic fragments with a little proportion of muscovite and calcite (e.g., Figures 4e, h). Feldspar is rare and only found in sample JD-8, which precludes a potential felsic igneous source (Figure 4g). Quartz grains show moderate separation and sub-rounded to rounded shape, indicating that these grains underwent transport. Secondary overgrowths of quartz around their original grain edges can be easily recognized (e.g., Figure 4g). Lithic fragments mainly include volcanic clasts with cryptocrystalline texture, while rare sedimentary and/or metamorphic clasts can also be found (e.g., Figures $4 \mathrm{~g}, \mathrm{~h}$ ). Very small quantity of siltstones is also observed (e.g. Figure 4i), 
indicative of a weak hydrodynamic condition and long transport.

Framework components including quartz, feldspar, and lithic fragment with size $>62.5 \mu \mathrm{m}$, are applied for mineral framework analysis to help discriminate provenance types (Dickinson and Suczek, 1979; Dickinson et al., 1983; Dickinson, 1985). In the Nangqian-Xialaxiu Basin, besides four samples falling into the "undissected arc" region, five samples lie within the "recycled orogenic" region in the QtFL plot; by contrast, all the samples from the Gongjue Basin fall into the "recycled orogenic" region, displaying similar origin (Figure 5a). Furthermore, in the QmFLt plot, five samples collected in the Nangqian-Xialaxiu Basin lie within the "lithic recycled" region, while the remaining ones plot in the "transitional recycled" region; conversely, most samples from the Gongjue Basin fall into the field of "transitional recycled" with only one exception (sample JD-8), which plots into the "quartzose recycled" field due to its large quartz content (Figure 5b).

\subsection{Zircon U-Pb geochronology}

The various zircon age ranges and the major petrological characteristics for each sample are displayed in the supplementary material Table S1. The detrital zircon age ranges and corresponding age peaks could be divided into several groups. The U-Pb isotopic results are listed in the supplementary material Table S4 and then interpreted into concordia and relative probability density diagrams in Figures 7-9, respectively. A major age peak refers to age group that represent at least $20 \%$ of the total zircon population, whereas a minor peak refers to age group representing less than $20 \%$ but more than $10 \%$ of total zircon population. 


\subsubsection{Zircon $\mathrm{U}-\mathrm{Pb}$ ages from samples in the Nangqian-Xialaxiu Basin}

The zircon grain morphologies vary from euhedral to rounded with an average size ranging between $50 \mu \mathrm{m}$ to $250 \mu \mathrm{m}$. Among a total of 332 detrital zircon crystals analyzed (NQ14-01, NQ14-02, and XL14-02), 313 of them present a discordance lower than $10 \%$ (Figure 7; Table S4 in the supplementary material). Crystal morphology and clear oscillatory zoning indicate a magmatic origin. While some zircon grains have low $\mathrm{Th} / \mathrm{U}$ ratios, the $\mathrm{Th} / \mathrm{U}$ ratios for most of them vary from 0.10 to 2.09, which reflects a dominant magmatic origin for these grains (Figure 7; Table S1 in the supplementary material) (Hanchar and Rudnick, 1995; Hoskin and Black, 2000; Corfu et al., 2003).

Zircon U-Pb ages of the three samples (NQ14-01, NQ14-02, and XL14-02) range from $40 \mathrm{Ma}$ to $2974 \mathrm{Ma}$, and have two predominant populations at 220-280Ma and $405-445 \mathrm{Ma}$, constituting more than $80 \%$ of the total population (Figure 8). For all the samples, a small proportion of the zircon grains present Precambrian ages. With the exception of one grain with an age of $197 \pm 2 \mathrm{Ma}$, all the grains from the Paleocene sample XL14-02 (Xialaxiu area) yield ages older than 200 Ma (Figure 7). This is different from the results obtained on the Early Eocene samples (i.e., NQ14-01 and NQ14-02) from the Nangqian area, where Jurassic-Cenozoic zircon grains are abundant, the youngest grain in sample NQ14-01 giving a concordant age of $40 \pm 1$ Ma (Figure 7; Table S4 in the supplementary material).

\subsubsection{Zircon U-Pb ages from samples in the Gongjue Basin}

Three hundred and eighty-seven analyses with discordance degree lower than $10 \%$ 
were obtained from a total of 530 zircon grains (i.e., GJ-7, GJ-24, JD-8, JD-14, and JD-21) (Figure 7; Table S4 in the supplementary material). The zircon grain morphologies vary from euhedral to rounded with an average size ranging between 50 $\mu \mathrm{m}$ and $200 \mu \mathrm{m}$, and more than $90 \%$ crystals display oscillatory zoning in CL images (Figure 6), implying a magmatic origin. Except for several grains with very low $\mathrm{Th} / \mathrm{U}$ values, the majority of the zircon $\mathrm{Th} / \mathrm{U}$ ratios mainly vary from 0.10 to 2.50 , indicating that they were largely derived from a magmatic source (Figure 7; Table S1 in the supplementary material).

All these five samples exhibit slightly variable population features and provenance signatures (Figure 9). Most analyses fall on or near the concordia line. The isotopic ages of detrital zircon have a wide distribution ranging from $200 \mathrm{Ma}$ to $2000 \mathrm{Ma}$, with three major peaks at 207-256 Ma, 423-445 Ma, and 1851-1868 Ma identified (Figure 9). Notably, several Cenozoic ages at 50 Ma and much older ages at $\sim 2500 \mathrm{Ma}$ are also found, and their distributions are different from sample to sample. Sixteen young zircon grains are detected from three samples (GJ-24, JD-8 and JD-21), indicating a possible Cenozoic magmatic source and constraining an Early Eocene maximum depositional age for the strata (Zhang et al., 2018). Ubiquitous Paleoproterozoic zircon $\mathrm{U}-\mathrm{Pb}$ ages are distributed sporadically in all samples. Even in sample JD-21, a minor peak at 2496 Ma can also be found, which occupies $11.1 \%$ of the total data in this sample (Figure 9; Table S1 in the supplementary material).

\section{Discussion}




\subsection{Provenance of the sediments in the Nangqian-Xialaxiu Basin}

Previous field and mapping investigations attributed the red beds in the Nangqian-Xialaxiu Basin to the Gongjue Formation. However, we have to abandon this classification because the lithostratigraphic age is different from the same formation in the Gongjue Basin (Qinghai BGMR, 1991; Tibet BGMR, 1993; Zhou et al., 2002; Studnicki-Gizbert et al., 2008). Horton et al. (2002) reinterpreted several basins in the Yushu-Nangqian area as distinct entities separated by fold-thrust structures according to syncontractional growth strata along the basin-margin structures, instead of what was previously described as a large contiguous basin that was broken into several sub-basins due to late deformation processes.

Approximate sedimentary source areas were previously recognized during basin development using paleocurrent data and conglomerate and sandstone compositional analyses (Horton et al., 2002; Zhou et al., 2002; Spurlin et al., 2005; Jiang et al., 2009; Du et al., 2011b). By using paleocurrent measurements, researchers have suggested that the Nangqian-Xialaxiu Basin was fed by sediments issued from proximal source areas composed of Carboniferous-Triassic rocks and from different directions (Wang et al. 2001b, 2002; Horton et al., 2002; Zhou et al., 2002; Jiang et al., 2009, 2011; Du et al., 2011b). In addition, paleocurrent analysis and mineral framework modes were also used for provenance analysis (e.g., Du et al., 2011b; Jiang et al., 2011; this study). In the QtFL plot, all sandstone component points fall into the recycled orogenic and undissected regions; in the QmFLt plot, they lie within transitional and lithic recycled regions (Figure 5). Mineral features, characterized by low compositional and textural 
maturity, include abundant lithic debris, indicating a short transportation and a rapid burial from a proximal source likely composed of Triassic strata (Figure 4). Here, we report new zircon $\mathrm{U}-\mathrm{Pb}$ geochronological results to constrain the provenance of the sediments in the Nangqian-Xialaxiu Basin.

The detrital zircon U-Pb geochronological data for three samples from the Nangqian-Xialaxiu Basin can be divided into two principal groups (Figure 8). Detrital zircons grains mainly range in age from $\sim 210$ Ma to $\sim 450$ Ma with two main peaks at 220-280 Ma and 405-445 Ma (Figures 8, 11; Table S3 in the supplementary material). Despite different sampling locations and strata layers, the age peaks in these three samples are similar, suggesting invariable and analogous source areas during the basin development (Figures 3, 8). The closest terranes to the Nangqian-Xialaxiu Basin include five potential source areas with distinct zircon age spectrums (the eastern Qiangtang Terrane, the western Qiangtang Terrane, the eastern Kunlun Range, the Songpan-Ganzi Terrane, and the Yidun Block). The two age peaks of the main populations in the Nangqian-Xialaxiu Basin overlap with the age distributions recorded in the detrital zircon populations from the eastern Qiangtang Terrane (Figure 10e), and we exclude the remaining potential source areas based on several reasons: 1) the age peak at $\sim 1850 \mathrm{Ma}$ is very significant in the Songpan-Ganzi Terrane but absent in the Nangqian-Xialaxiu Basin (Figure 10c) (Bruguier et al., 1997; Enkelmann et al., 2007; Weislogel et al., 2010; Zhang et al., 2014); 2) the prominent age peak at 900 Ma is significant in the western Qiangtang Terrane and Yidun Block but lacking in the Nangqian-Xialaxiu Basin (Figures 10f, 10g) (Dong et al., 2011; Gehrels et al., 2011; 
Zhu et al., 2011; Ding et al., 2013; Wang et al., 2013; Liu et al., 2016); 3) although the age distributions in the Nangqian-Xialaxiu Basin correspond to the characteristic ages of the eastern Kunlun Range, the short drainage system and proximal deposition preclude this possibility (Figure 10d) (Horton et al., 2002; Spurlin et al., 2005; Du et al., 2011a, 2011b); 4) Jurassic-Cretaceous zircon grains found in sample NQ14-02 from Nangqian area are evidenced in sedimentary strata exposed in the eastern Qiangtang Terrane (Figure 10e) (Gehrels et al., 2011; Ding et al., 2013); 5) previous published detrital zircon $\mathrm{U}-\mathrm{Pb}$ age from the southern side of the Jinsha suture zone, e.g., sample 2004T030 studied by Ding et al. (2013) (Figure 1b), is close to the Nangqian-Xialaxiu Basin but shows distinctive age spectrum (Figure 11e), which also precludes large-distance sedimentary transport for sediments in the studied basin. Furthermore, the source of sample 2004T022 studied by Ding et al. (2013) (Figure 1b), yielding a major peak at $262 \mathrm{Ma}$ and a minor peak at $437 \mathrm{Ma}$, has been interpreted to be derived from the eastern Kunlun Range across the extended Hoh-Xil Basin (Figure 11c) (Ding et al., 2013). However, it is mysterious that no characteristic ages of the Songpan-Ganzi Terrane contribute to this sample after such a long journey. Additionally, age distributions in this sample also match well with the ages in the adjacent Triassic plutons and a small gneissic unit within Ordovician strata, which appears to provide a more reasonable source for the sample $2004 \mathrm{~T} 022$ (Figure 1) (Roger et al., 2003). These Triassic plutons and Ordovician strata probably also contributed an eastern-northeastern source for the detritus in the Nangqian-Xialaxiu Basin. Besides materials coming from the east-northeast, the Jurassic-Cretaceous 
zircon grains found in sample NQ14-02 were possibly derived from the nearby Jurassic-Cretaceous strata to the southeast (Figure 1). Finally, sporadic young zircon grains in our samples are in accordance with igneous rocks found in the basin. We conclude that detrital zircon U-Pb ages reveal that the sediments in the Nangqian-Xialaxiu Basin were predominantly derived from the nearby uplifted fold belts and/or thrust sheets. This conclusion is in good agreement with interpretation of Horton et al. (2002) that the individual rivers within the Nangqian-Yushu region were generally no more than 50-km long.

\subsection{Provenance of the sediments in the Gongjue Basin}

Previous analyses of sedimentary facies indicate that the well-rounded cobble conglomerate near the bottom of the basin were sourced from the adjacent Paleozoic and Triassic units in the hanging wall of the east-bounding thrust fault (Yin and Harrison, 2000; Studnicki-Gizbert et al., 2008), coincident with easterly paleocurrents derived from large oblique bedding in the overlying strata (e.g., Figures $4 b-c)$. In the northern part of the Gongjue Basin, southeast-directed paleocurrent and dominant limestone gravels also suggested a nearby Triassic marine source (Tang et al., 2017). Overlying these coarse strata, the provenance of the predominant basin materials, composed of thinly bedded, fine sandstone, siltstone, and mud-sized sediments with a total thickness up to $3 \mathrm{~km}$, remains enigmatic.

Fine- and medium-sized sandstone samples are mainly composed of quartz and lithic fragments, mostly of volcanic origin. The high content of quartz and volcanic detritus indicates magmatic sources, while the extremely low amount of feldspar 
excludes the possibility that the sources were in a close vicinity. This is also confirmed by the mineral morphology characterized by sub-angular to sub-rounded shape and medium sorting (Figures $4 \mathrm{e}-\mathrm{h}$ ) and by the sub-rounded to rounded shapes of the zircon grains (Figure 6). Correspondingly, the modal components of these sandstone samples obtained by the updated Gazzi-Dickinson counting method also suggest a sedimentary derivation from recycled orogenic source areas as all the samples fall into the recycled orogenic field in the QtFL plot and transitional recycled field in the QmFLt plot, with the exception of sample JD-8 (Figure 5) (Ingersoll et al., 1984; Dickinson, 1985). Furthermore, the scarcity of feldspar in the Gongjue Basin implies that igneous rocks were not the prime source (see above) and suggests that intrusive rocks, such as granite, were not yet at the surface and were, therefore, unable to supply materials for the Gongjue Basin.

Even though recycled sediment influx, evidenced in the Dickinson triangular plots, are consistent with the petrological interpretation in the Gongjue Basin, provenance analysis based on these qualitative plots alone is not sufficient. Indeed, adjacent fold/thrust belts and terranes/blocks, such as Nangqian-Yushu fold belt and Jiangda thrust belt, and distant terranes/blocks surrounding the Gongjue Basin as Yidun Block to the east and Songpan-Ganzi Terrane to the north, are all potential source areas. Here, our detrital zircon $\mathrm{U}-\mathrm{Pb}$ geochronology, together with previously published isotopic geochronologic data from the nearby terranes/blocks, helps to precisely constrain the provenance of the sediments in the Gongjue Basin.

Because the zircon U-Pb results obtained for each sample from the Gongjue 
Basin are very similar, we combined the five age spectrums as a single one for further discussion (Figure 9). Three major peaks at 207-256 Ma, 423-445 Ma, 1851-1868 Ma, and two minor peaks at $\sim 50 \mathrm{Ma}$, and $\sim 2500 \mathrm{Ma}$ can be identified (Figure 9; Table S4 in the supplementary material). The age distribution patterns from the Gongjue Basin are remarkably similar to that of detrital zircon grains from the Songpan-Ganzi Terrane but strikingly different from that of detrital zircon grains from the eastern Kunlun Range, the western Qiangtang Terrane and the Yidun Block for the following reasons: 1) the Yidun Block is mainly composed of the Yidun arc and the Zhongza massif, but the dominant age peak of the latter at $\sim 900 \mathrm{Ma}$ is not obvious in the Gongjue Basin (Figure 10g) (Wang et al., 2013; Wu et al., 2016); 2) the prominent 500-1000 Ma tectono-thermal events recorded in the western Qiangtang Terrane (related to the assemblage and breakup of the Gondwana supercontinent), is sporadic in the Gongjue Basin (Figure 10f) (Zhu et al., 2011); 3) the high-pressure metamorphic minerals (e.g., garnet, phengite, epidote, omphacite) of the Qiangtang metamorphic belt (QMB) which extends between the western Qiangtang Terrane and Gongjue Basin, are not present in our samples (Figures 1, 4) (Kapp et al., 2000; Zhang et al., 2006a, b; Pullen et al., 2011; Zhai et al., 2011b; Zhu et al., 2013); 4) the absence of metamorphic zircon grains which are ubiquitous in the QMB also exclude the possibility that the sediments originated from the SW and SWW directions (Figures 1, 7).

In contrast, among the five dominant age distributions recorded in the detrital zircon populations from the Gongjue Basin, the three major age peaks at 207-256 Ma, 
423-445 Ma, 1851-1868 Ma correlate well with those of the detrital zircon grains from the Songpan-Ganzi Terrane, suggesting a predominant source area for the studied region (Figure 10c) (Enkelmann et al., 2007; Weislogel et al., 2010; Gehrels et al., 2011; Ding et al., 2013; Zhang et al., 2014). The Gongjue Basin is controlled by boundary faults, and these thrusts also provided a small quantity of materials into basin. It is further evidenced by the detrital zircon grains that the age peaks at $\sim 230$ $\mathrm{Ma}$ and $\sim 430 \mathrm{Ma}$ in the eastern Qiangtang strata are significant in the Gongjue Basin. (Figures 10c, 10e).

Additionally, the lack of $200-60$ Ma old zircon grains in the Gongjue Basin suggests the source cannot be from the western part of the eastern Qiangtang Terrane where abundant occurrence of Jurassic zircon grains are reported (Figures 9, 10f) (Ding et al., 2013). The previous published zircon ages from surrounding Triassic strata are different from the age spectrums found in the Gongjue Basin (Figure 11), but similar to the age populations found in the western Qiangtang Terrane (e.g., sample 2003 T058 studied by Ding et al. 2013) (Figures 10f, 11d) and the Yidun Block (e.g., samples 2003 T066 studied by Ding et al. 2013, GB101, GB133, GB185, and GB417 studied by Wang et al. 2013) (Figures 10g, 11g), respectively. This also implies that the source regions for the sediments from the Gongjue Basin cannot be the Triassic strata sequence to the west or the Yidun Block to the east (Figures 1, 11) (Ding et al., 2013; Wang et al., 2013). Finally, the source of the young zircon population ( 52 Ma) of the Gongjue Basin (Zhang et al., 2018) were most likely originated from the $\sim 51-49 \mathrm{Ma}$ volcanics in the Xialaxiu area, $200 \mathrm{~km}$ to the 
northwest of the Gongjue Basin, which implies that the Gongjue Basin was located at a lower altitude than the Xialaxiu region during this period. Hence, we conclude that the most likely sources of zircon for the Gongjue Basin are the Songpan-Ganzi Terrane, with minor materials sourcing from the surrounding thrust/fold belts which were activated or reactivated during the India-Asia collision (Roger et al., 2000; Yin and Harrison, 2000; Studnicki-Gizbert et al., 2008).

\subsection{Tectonic implications for the eastern Tibetan Plateau}

Our results indicate that the Nangqian-Xialaxiu and Gongjue basins contain sediments that were clearly derived from distinct source regions (Figures 10, 12). In the Nangqian-Xialaxiu Basin, sources are the adjacent orogenic belts, which is in agreement with the observed facies. In the Gongjue Basin, dominated source of the remote Songpan-Ganzi Terrane is in agreement with observed fine-grained sediments that experienced long-term hydrodynamic transport. Basin development controlled by specific tectonic settings can further explain this difference.

One explanation could be that the Nangqian region is more thin-skinned while the Gongjue region may be reactivating an older basement structure (Spurlin et al., 2005; Studnicki-Gizbert et al., 2008). Growth-strata widespread along the thrust indicated that sedimentation was synchronous with initial fold-thrust deformation in the Nangqian-Xialaxiu Basin (Horton et al., 2002). Using balanced cross sections across the Nangqian-Yushu area and related basins, Spurlin et al. (2005) proposed that a nearly $40 \%$ upper-crustal shortening, occurring in the early Cenozoic, was distributed over the area. This shortening possibly accounted for most of the surface 
uplift of the Nangqian region, resulting in moderate-elevation intermontane drainage basins and surrounding relatively high-elevation fold-thrust belts. Horton et al. (2002) proposed that the activation of these fold-thrust belts was the consequence of contraction triggered by the India-Asia collision. Sediment accumulation during early Cenozoic in the Nangqian-Xialaxiu Basin is related to the synchronous fold-thrust deformation (Horton et al., 2002), which coincides with our provenance analysis in this region. In the Gongjue Basin, however, Studnicki-Gizbert et al. (2008) suggested that the shortening was limited to the bounding faults along the eastern limb of the basin, resulting in much less surface deformation and uplift of the whole region. Therefore, the Gongjue Basin, developed as a foreland basin, only partially received materials from the eastern thrusts. As a result, the majority of sediments in the relatively low-elevation Gongjue Basin (Tang et al., 2017) were derived from higher-elevation mountains, i.e., the Songpan-Ganzi orogenic belts.

Paleomagnetic results also matches well with specific tectonic settings of the Nangqian-Xialaxiu and Gongjue basins. Compared to the Nangqian region, the Gongjue region is more to the side of the collision which records a more oblique contraction with more strike slip component, rotation and less deformation. In the Nangqian-Yushu area, the tectonic pattern absorbing the upper crustal contraction is fold-thrust deformation with small $\left(\sim 7^{\circ}\right)$ clockwise rotation relative to the Eurasian appear polar wander path (APWP) since 38-37 Ma in the Nangqian basin and negligible rotation since 51-49 Ma in the Xialaxiu Basin (Roperch et al., 2017). In contrast, the Gongjue Basin has experienced a cumulative clockwise rotation of 
$24.1 \pm 3.1^{\circ}$ relative to the Eurasian APWP since $\sim 52 \mathrm{Ma}$ (Zhang et al., 2018). Hence, distinct tectonic settings directly affected the development and sedimentology of the Nangqian-Xialaxiu and Gongjue basins.

As the dominant erosion regions, the fold/thrust belts are critical to these drainage basins. The Nangqian-Yushu fold/thrust belts and the Songpan-Ganzi orogenic belts formed and reactivated in response to the India-Asia collision and continued convergence, constituting dominant source areas for the Nangqian-Xialaxiu and Gongjue basins, respectively. But when and how did these fold/thrust belts supply the large amount of sediment inputs to the Nangqian-Xialaxiu and Gongjue basins? By combining the available provenance results and deformation/rotation history of these two basins, we propose a comprehensive scenario in three stages for the Cenozoic paleogeographic evolution of the eastern Tibetan Plateau (Figure 12).

Stage I: Paleocene time (Figure 12a). Contemporaneously with or shortly after the onset of the India-Asia collision (DeCelles et al., 2014; Huang et al., 2015; Hu et al., 2016), crustal shortening and contractional deformation became widespread in the Nangqian region, marked by activity of the several thin-skinned thrust belts (e.g., Shanglaxiu, Xialaxiu, Niuguoda thrust belts and Nangqian fault zones). Among these thrust belts, several small-scale intermontane depocenters developed independently (Figure 12a). Initial accumulated sediments were derived from relatively small internal drainage networks and short main-stem rivers in this region (Horton et al., 2002).

Deformation of the Songpan-Ganzi orogenic belts originally occurred during the 
Indosinian orogeny (ca. 230-200 Ma) (Harrowfield and Wilson, 2005; Roger et al., 2010), and was reactivated in the early Cenozoic as a result of the India-Asia collision (Roger et al., 2010). These deformations within the belts can be clearly identified by the reactivation of the Triassic high angle faults, folds, and large scale folding of the décollement of the accretionary belt (Roger et al., 2010, 2011). High-relief erosional removal from the Songpan-Ganzi orogenic belts presumably offers substantial material to neighboring low-altitude areas, e.g., the Changsha-Gongma basin (Dai et al., 2013) (Figure 12a). Cenozoic upper crustal shortening in the Gongjue area is insignificant (Studnicki-Gizbert et al., 2008), and exposed pre-Cenozoic sediments underwent limited erosional denudation.

Stage II: Eocene time (Figure 12b). Successive Cenozoic contraction, induced by the India-Asia collision, continued in the eastern-central Tibet. Southwest-directed shortening led to a 61-km crustal shortening in the Nangqian area (Spurlin et al., 2005). This shortening deformation further triggered these thrust belts which provided substantial materials to the nearby Nangqian-Xialaxiu Basin (Figure 12b). Based on the carbonate stable and clumped isotopic evidence, the Nangqian basin was 2.7 $(+0.6 /-0.4) \mathrm{km}$ in elevation while the hypsometric mean elevation of surrounding mountains was $3.0 \pm 1.1 \mathrm{~km}$ above sea level during this period (Li et al., 2018a).

The Songpan-Ganzi orogenic belts further uplifted and eroded during this time, as indicated by the low-temperature thermochronological studies (Dai et al., 2013). In addition, based on calculated paleoelevations obtained from oxygen and carbon stable isotopes (Tang et al., 2017), the Gongjue region with an average elevation of 
2100-2500 $\mathrm{m}$ became a drainage basin during the Eocene. This relatively low-elevation suggested that the Gongjue region was located at the edge of the proto-plateau during this period (Figure 12b). Major rivers originating from the Songpan-Ganzi orogenic belts, therefore, transported long distance across the Jinsha suture and carried volumetrically significant materials into the Gongjue Basin (Figure $12 b)$.

Stage III: Oligocene-present (Figure 12c). Erosional unroofing of the high-relief Songpan-Ganzi and Nangqian-Yushu orogenic belts decreased. These orogenic belts were incapable to provide erosional removal for studied basins. Sediment accumulation in these basins was terminated in the eastern Tibetan Plateau by the late Eocene time and tectonic evolution had entered a post-basin stage since then. Strike-slip faulting unequivocally postdates sedimentation, i.e., Ganzi-Yushu fault and Litang fault (Spurlin et al., 2005; Studnicki-Gizbert et al., 2008) (Figure 12c). The Gongjue Basin, previously acting in the edge of the plateau, became a hinterland basin due to the intense uplift and eastern expansion of the plateau (Figure 12c). The elevation of the Nangqian basin was uplifted an additional 1.1-1.2 km since the late Eocene (Li et al., 2018a). The Gongjue Basin uplifted $\sim 2 \mathrm{~km}$ to its present height since the late Eocene (Tang et al., 2017). 1700 to $2600 \mathrm{~m}$ of uplift may have occurred between the late Eocene and early Miocene in the Hoh-Xil basin (Polissar et al., 2009). Meanwhile, the Jinsha suture was incised deeply during the Neogene (Horton et al., 2002; Duvall et al., 2012). This is in a good agreement with tectonic models depicting uplift and deformation of a proto-Central Plateau (Li et al., 2015b; Wang et al., 2008; 
2014; Yi et al., 2008), rather than plateau growth from south to north (Tapponnier et al., 2001).

Finally, large thrust nappe structure was predominant in eastern Tibet, and low-relief geomorphic Paleogene surfaces had experienced negligible erosion since then. This landform was similar to modern conditions across much of the interior of the Tibetan Plateau (Rohrmann et al., 2012).

\section{Conclusions}

Analysis of $\mathrm{U}-\mathrm{Pb}$ ages of detrital zircon collected from the Paleocene-Eocene sedimentary rocks in the Nangqian-Xialaxiu and Gongjue basins, together with available petrography and sandstone detrital modes, provide new information to constrain the source regions and the tectonic evolution of the Cenozoic basins in the eastern Tibetan Plateau. In summary, this study allows us to propose these main conclusions as follows:

(1) Three hundred and thirteen effective detrital zircon ages from three samples collected in the Nangqian-Xialaxiu Basin yield two prominent age peaks at 220-280 Ma and 405-445 Ma. Three hundred and eighty-seven detrital zircon ages from five samples in the Gongjue Basin exhibit three predominant age populations at 207-256 Ma, 423-445 Ma, and 1851-1868 Ma with two subordinate age peaks at 50 Ma and $\sim 2500$ Ma.

(2) According to the age data of detrital zircon grains in the adjacent areas and surrounding terranes, together with other evidences such as paleocurrent analysis, petrography, zircon morphology, and mineralogical framework analysis, we suggest 
that the Nangqian-Xialaxiu Basin received dominantly recycled materials from neighboring thrust belts. In contrast, the Gongjue Basin accumulated prominent recycled detritus from the remote Songpan-Ganzi orogenic belts, with a minor contribution from the subordinate surrounding mountain systems.

(3) Distinct tectonic settings can be well related to the different source regions for the Nangqian-Xialaxiu and Gongjue basins. Adjacent high-relief fold-thrust belts induced by compressive stress supplied materials to the Nangqian-Xialaxiu Basin, whereas upper crustal shortening was limited and high local topographic reliefs of orogenic belts are not obvious in the Gongjue region. As a result, the remote Songpan-Ganzi complex contributed to the voluminous materials found in the Gongjue Basin via north- or northeast-directed drainage channels.

(4) Three stages of tectonic evolution during Cenozoic in the eastern Tibetan Plateau are proposed. In the Paleocene, shortly after the onset of the India-Asia collision, the Nangqian-Xialaxiu Basin appeared as a set of small intermountain sub-basins and received substantial materials from the surrounding thrust belts. In the Eocene, the Gongjue Basin situated at the edge of a proto-Plateau and remained a relatively low-elevation, and received crucial deposits from the remote relatively high-relief Songpan-Ganzi orogenic belts. Since the Oligocene after depositional termination, the Gongjue Basin has evolved as part of orogenic belts and uplifted to its present elevation, which is coincident with the eastward propagation of the plateau. The Nangqian basin accepted additional post-late Eocene elevation increase to its present elevation. 


\section{Acknowledgments}

This study is supported by National Science and Technology Major Project (No. 2017ZX05008001). We are grateful to editor Paul Hesse, Dr. Yang Qiong-Yan, and another anonymous reviewer, whose insightful and detail comments were greatly helpful to improve the clarity and interpretations of the manuscript. Yu Xiang-Jiang is also appreciated for his careful and fluent modification on our draft. 


\section{Figures and captions}

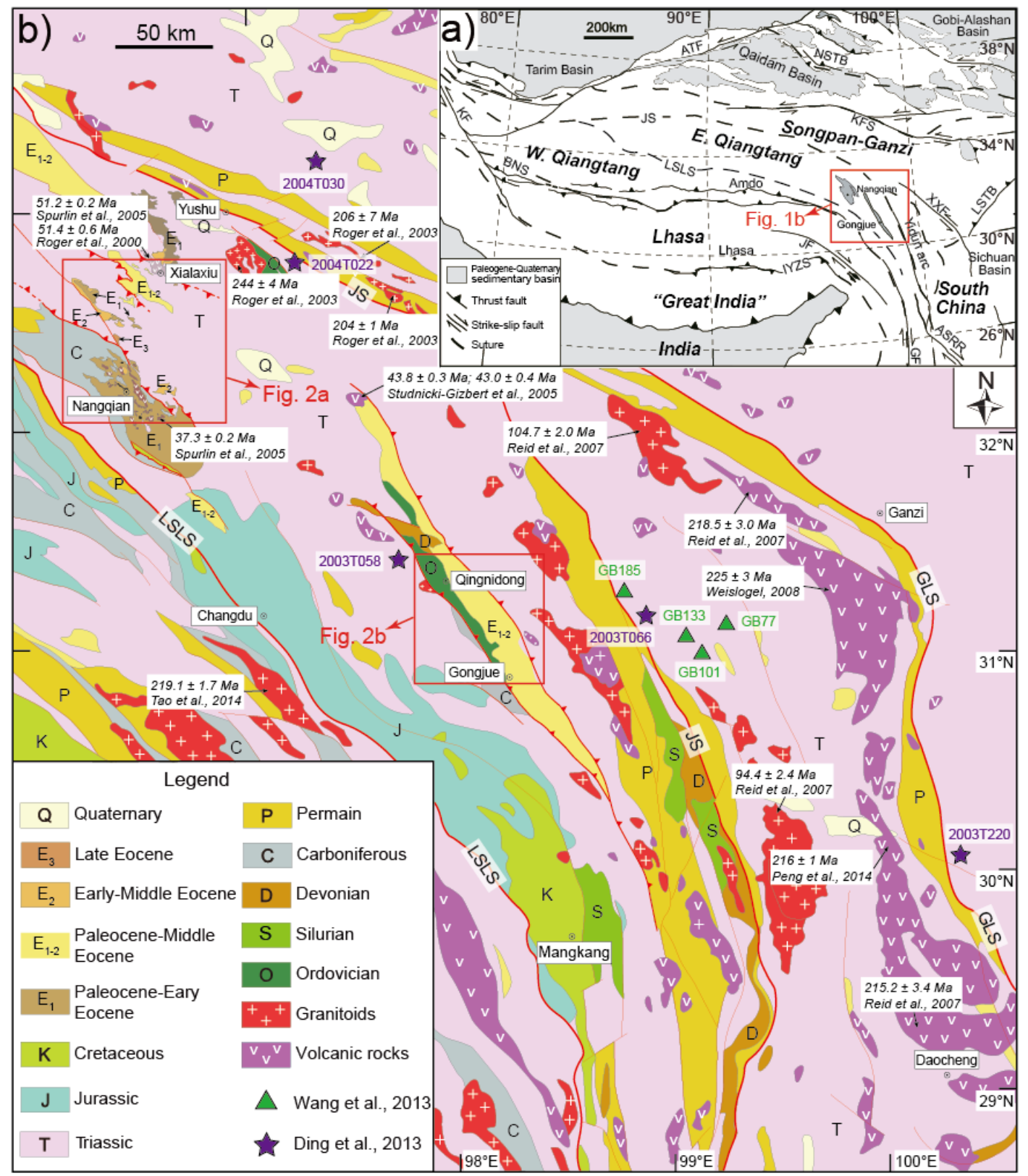

Figure 1. (a) Simplified tectonic map of the Tibetan Plateau, modified from Spurlin et al. (2005).

(b) Tectonic framework of the eastern Tibetan Plateau adapted from Qinghai BGMR (1991),

showing tectonic units, the suture belts between units, and the location of study areas; the

locations of the previous detrital zircon samples are also marked in blue triangle and purple star.

ATF: Altyn Tagh fault; NSTB: Nan Shan thrust belt; KFS: Kunlun fault system; JS: Jinsha suture;

KF: Karakorum fault; LSLS: Longmu Co-Shuanghu-Lancangjiang suture zone; BNS: 
Bangong-Nujiang suture; XXF: Xianshuihe-Xiaojiang fault system; LSTB: Longmen Shan thrust belt; ASRR: Ailao Shan-Red River fault; JF: Jiali fault; IYZS: Indus-Yarlung Zangbo suture zone;

GF: Gaoligong fault. 


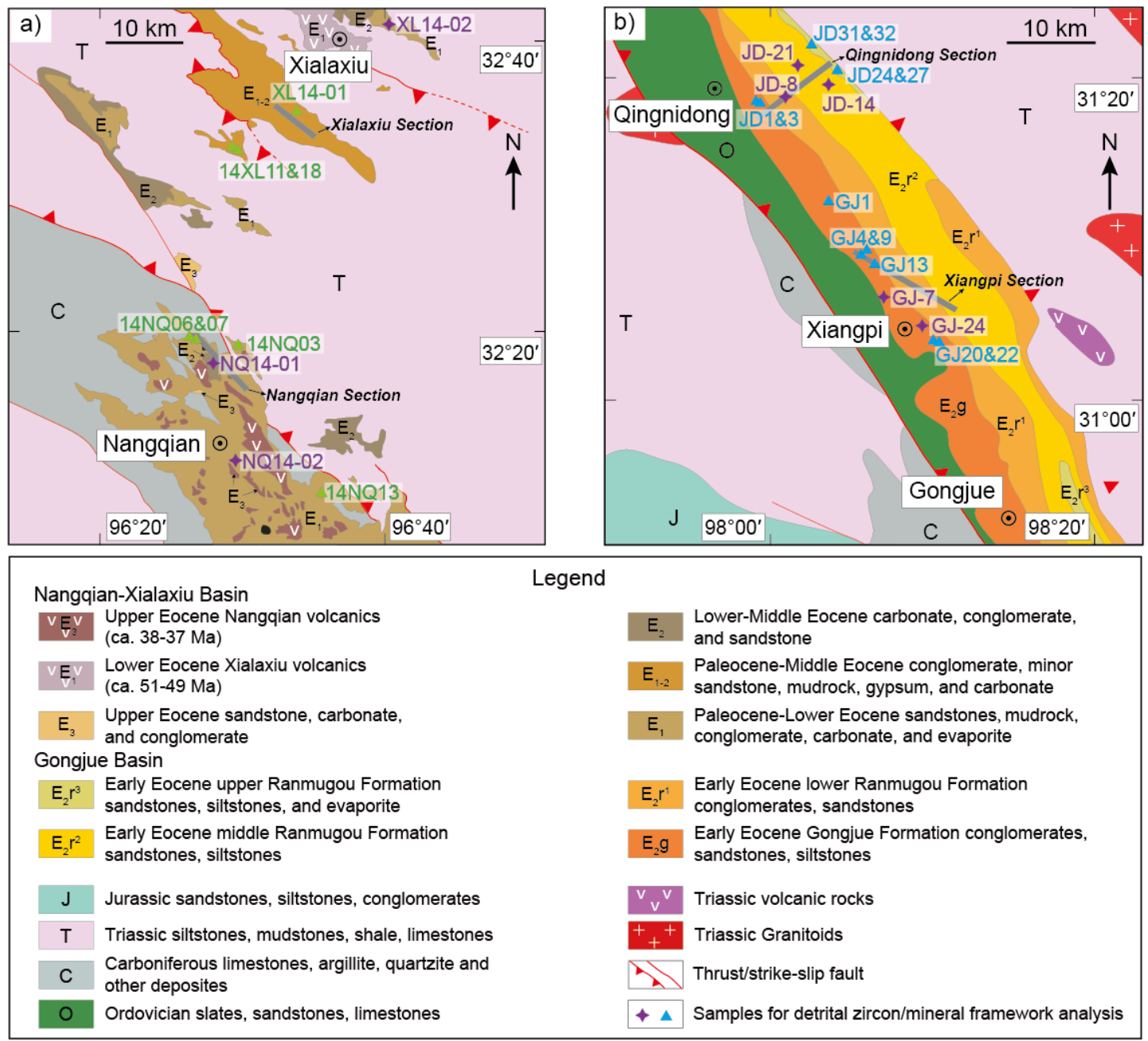

Figure 2. Geological map and locations of measured samples in (a) the Nangqian-Xialaxiu and (b)

Gongjue basins, respectively (modified from Spurlin et al. (2005), Tang et al. (2017), and 1:200000 geological maps (Qinghai BGMR, 1991)). 


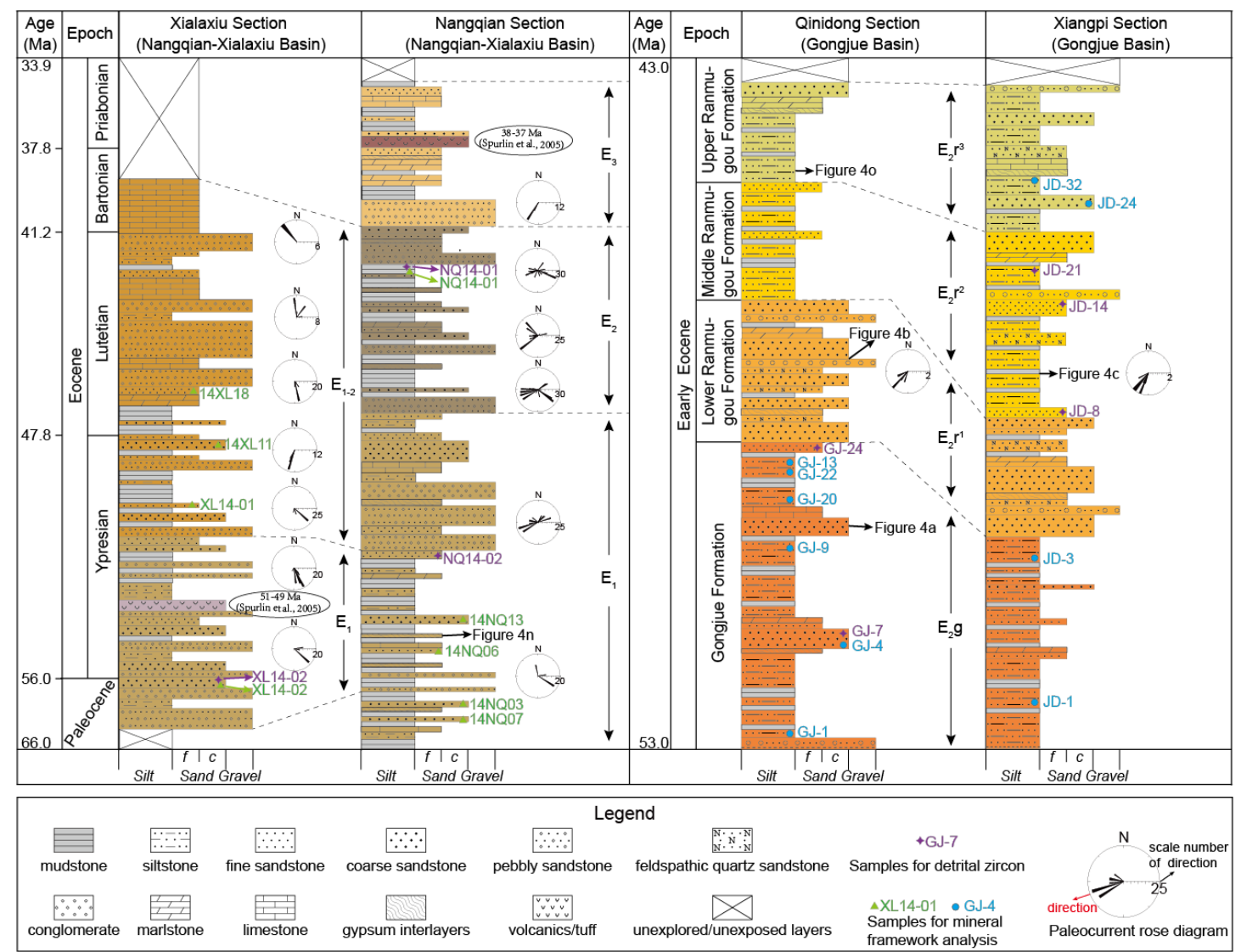

Figure 3. Comprehensive stratigraphic column and sampling locations of the Paleocene-Eocene strata in the Nangqian-Xialaxiu and Gongjue basins (modified from Spurlin et al. (2005), Du et al., (2011a, 2011b), Tang et al. (2017), and 1:200000 geological maps (Qinghai BGMR, 1991 and Tibet BGMR, 1993)). Paleocurrent directions in the Nangqian-Xialaxiu Basin cited Horton et al. (2002). 

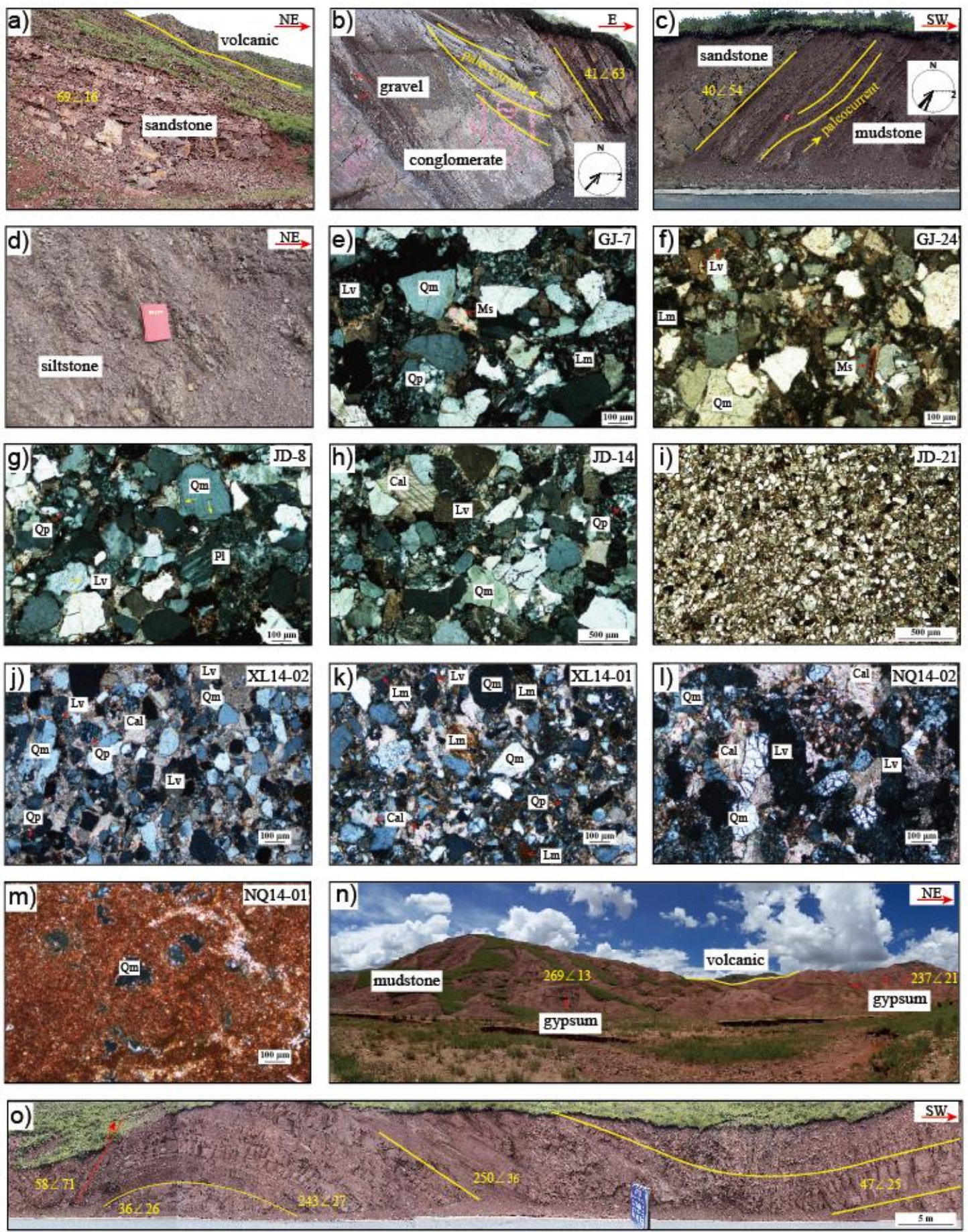

Figure 4. Representative field photographs and observations under microscope in (a-i, o) the

Gongjue and (j-n) Nangqian-Xialaxiu basins, respectively. (a) Early Eocene sandstone in the study

area and late Triassic volcanic in the background. (b-c) Large scale cross-bedding indicates

NE-directed paleocurrent. (d) Broken siltstone in the core of the basin-scale syncline. (e-h)

Mineralogical characteristics of sandstone samples under microscope show predominant quartz 
and volcanic debris. (i) Siltstone sample is excluded for mineral framework mode with average grain size $<0.0625 \mathrm{~mm}$. (j-1) Mineral components show dominant quartz, volcanic debris, and calcite. Cracked quartz implies strong deformation. (m) Clay rock sample within separate quartz grain. (n) Large-scale inclined bedding shows slight SW direction in the Nangqian area. (o) Large-scale continued folds with interbedded fault along the Chengdu-Lhasa highway in the Gongjue Basin. 
a)

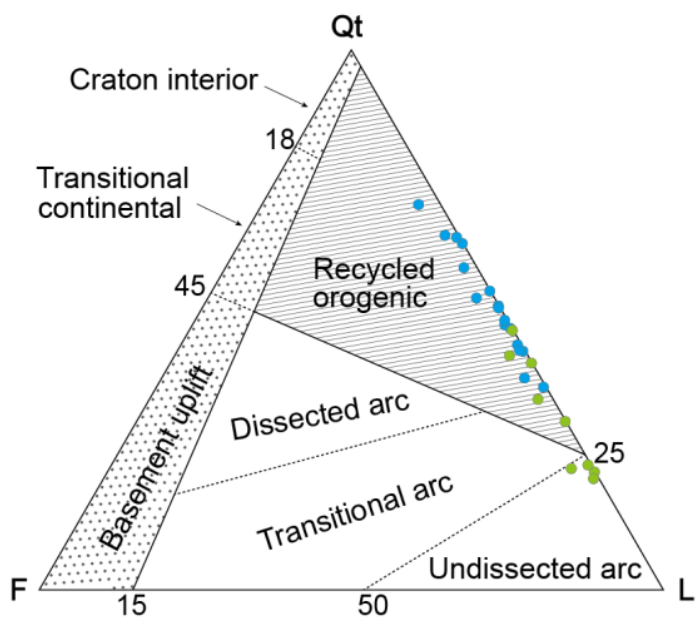

Provenance

categories b) Samples from Nangqian-Xialaxiu Basin

- Samples from Gognjue Basin
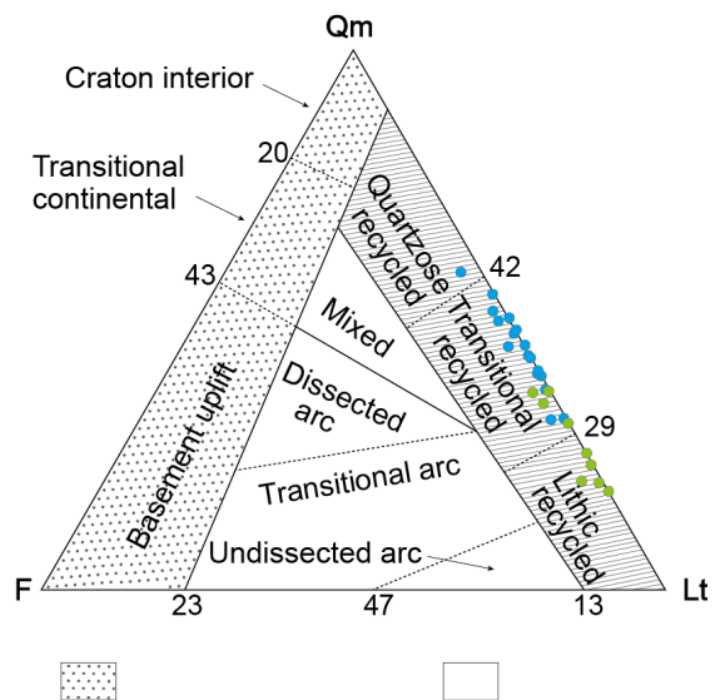

Continental block

Magmatic arc

Figure 5. Dickinson triangular plots of detrital components for the studied sandstones. (a) QtFL plot; (b) QmFLt plot. Parameters are from Dickinson and Suczek (1979). For raw data and abbreviations, see Table $\mathbf{S} 2$ in the supplementary material. 


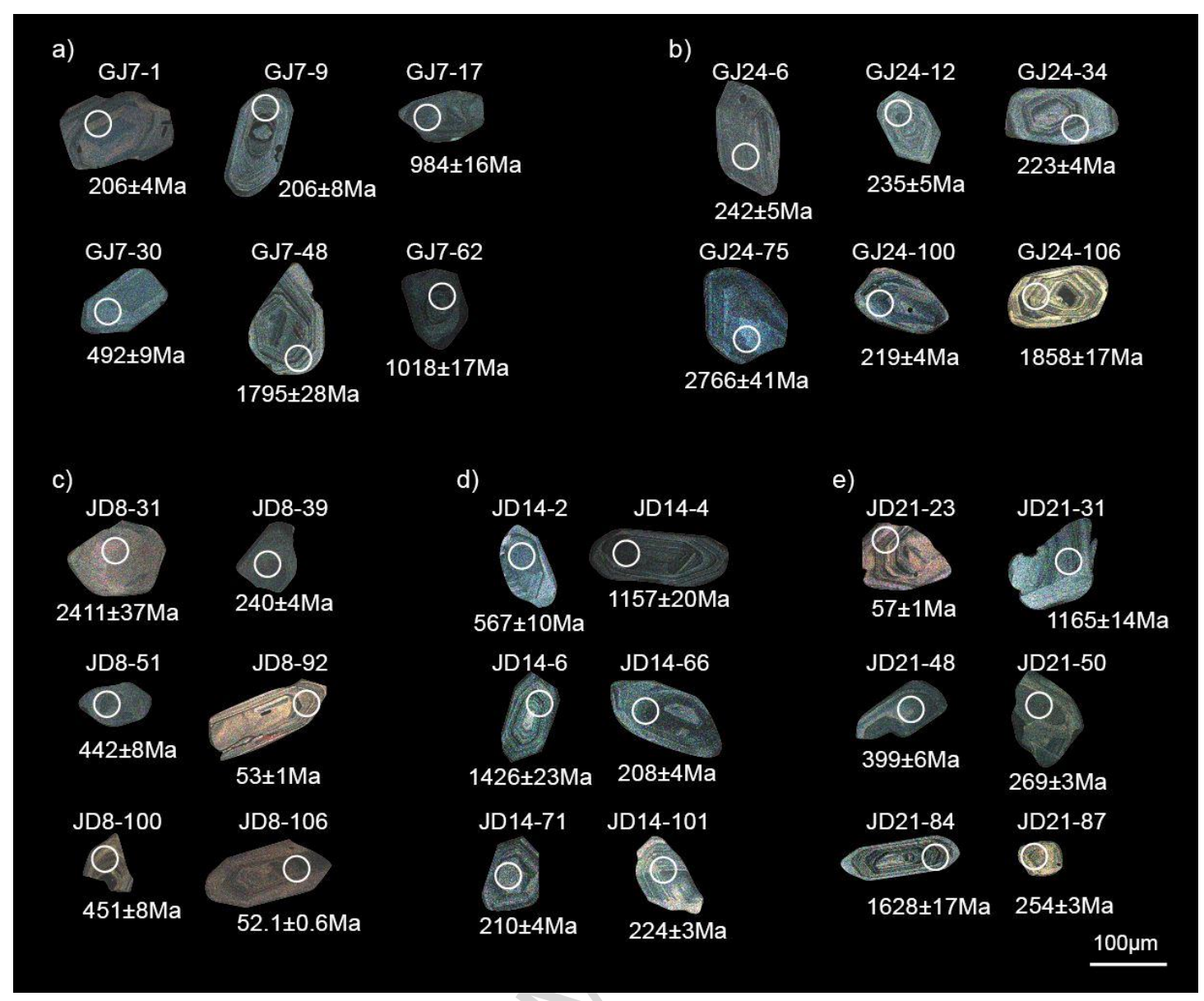

Figure 6. Representative CL images of detrital zircon from the Gongjue Basin showing internal structure and morphology. Well-preserved oscillatory zoning implies magmatic origin. Most zircons display sub-angular to sub-rounded outline, indicating long-distance transport. Some zircons in Cenozoic age exhibit slight pink such as samples JD-8 and JD-21. White circles are the spots of $\mathrm{U}-\mathrm{Pb}$ analysis. 
a)

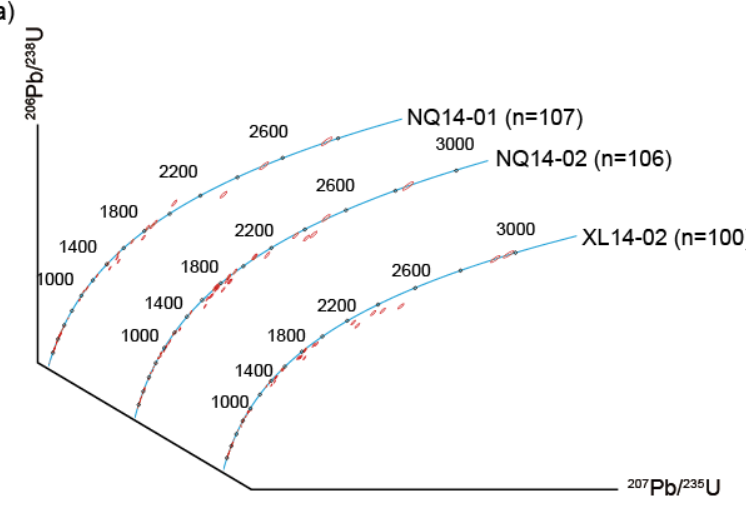

c)

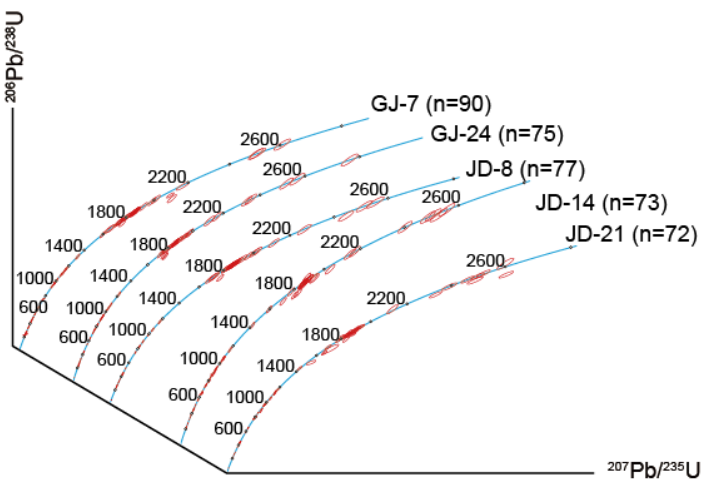

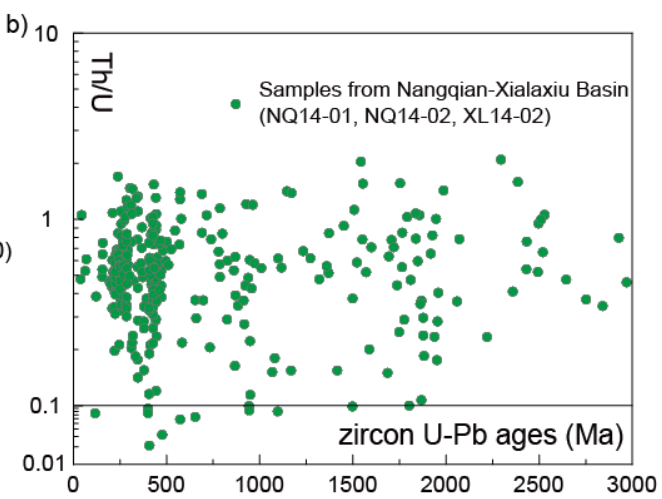

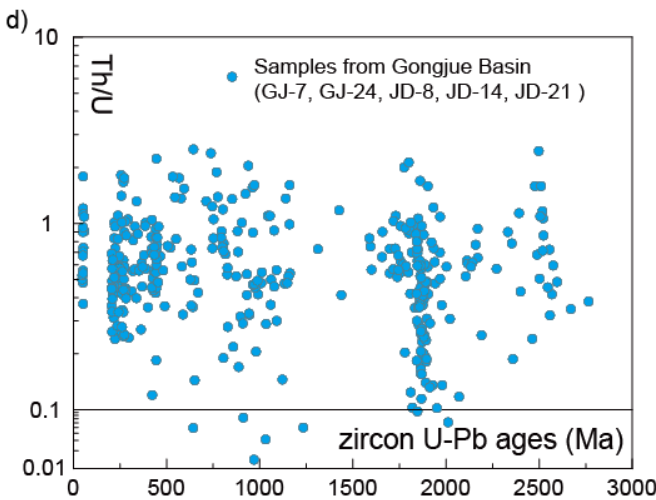

Figure 7. U-Pb concordia diagrams constructed using ISOPLOT (Ludwig, 2003) of detrital zircon collected from (a) the Nangqian-Xialaxiu and (c) Gongjue basins, respectively. The corresponding U-Pb ages vs. Th/U ratios of detrital zircon samples are shown in (b) and (d). Ages are in Ma and ellipses show $1 \sigma$ errors. 


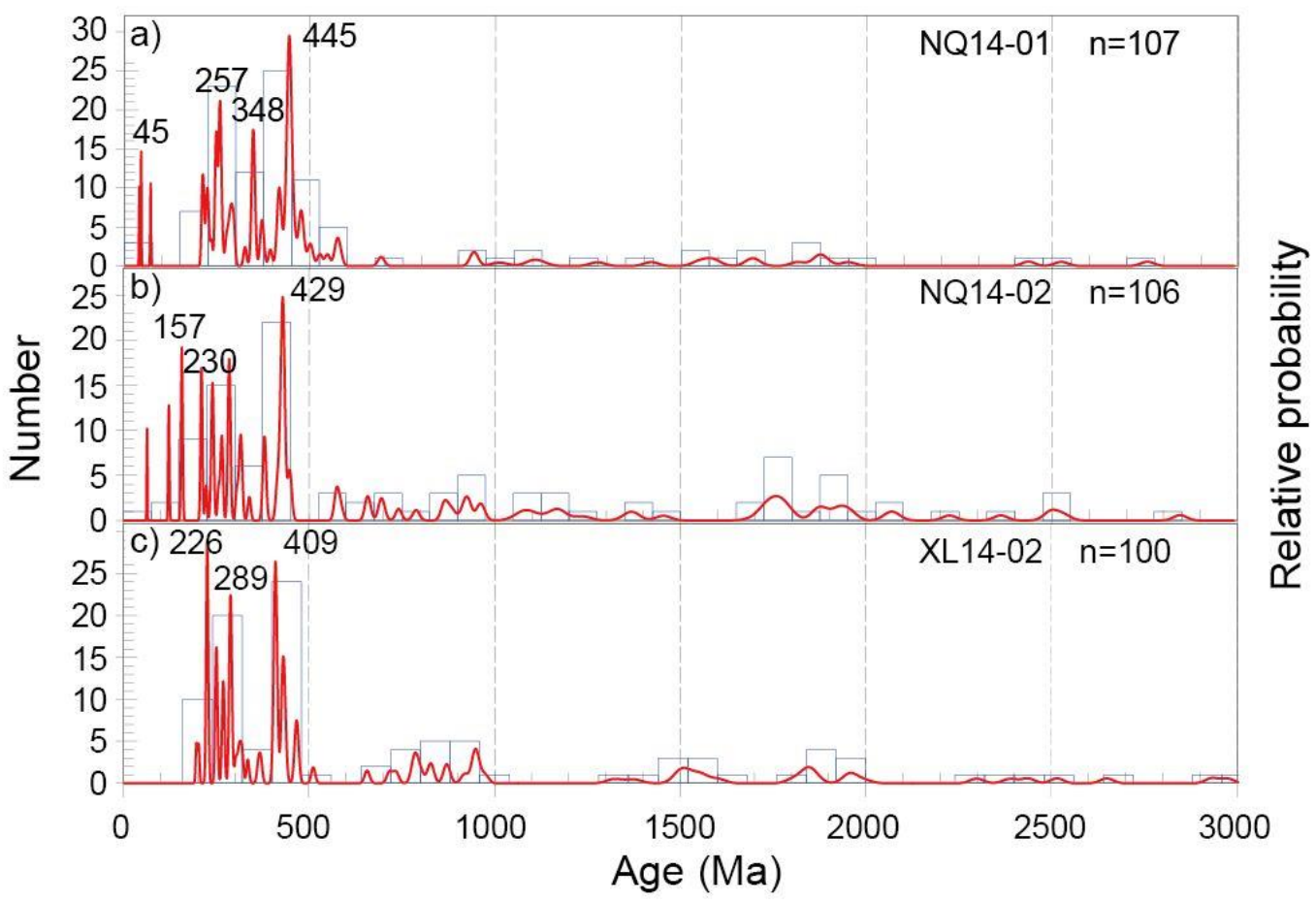

Figure 8. Relative age probability curves of U-Pb analysis on Paleocene-Eocene detrital zircon from the Nangqian-Xialaxiu Basin. 


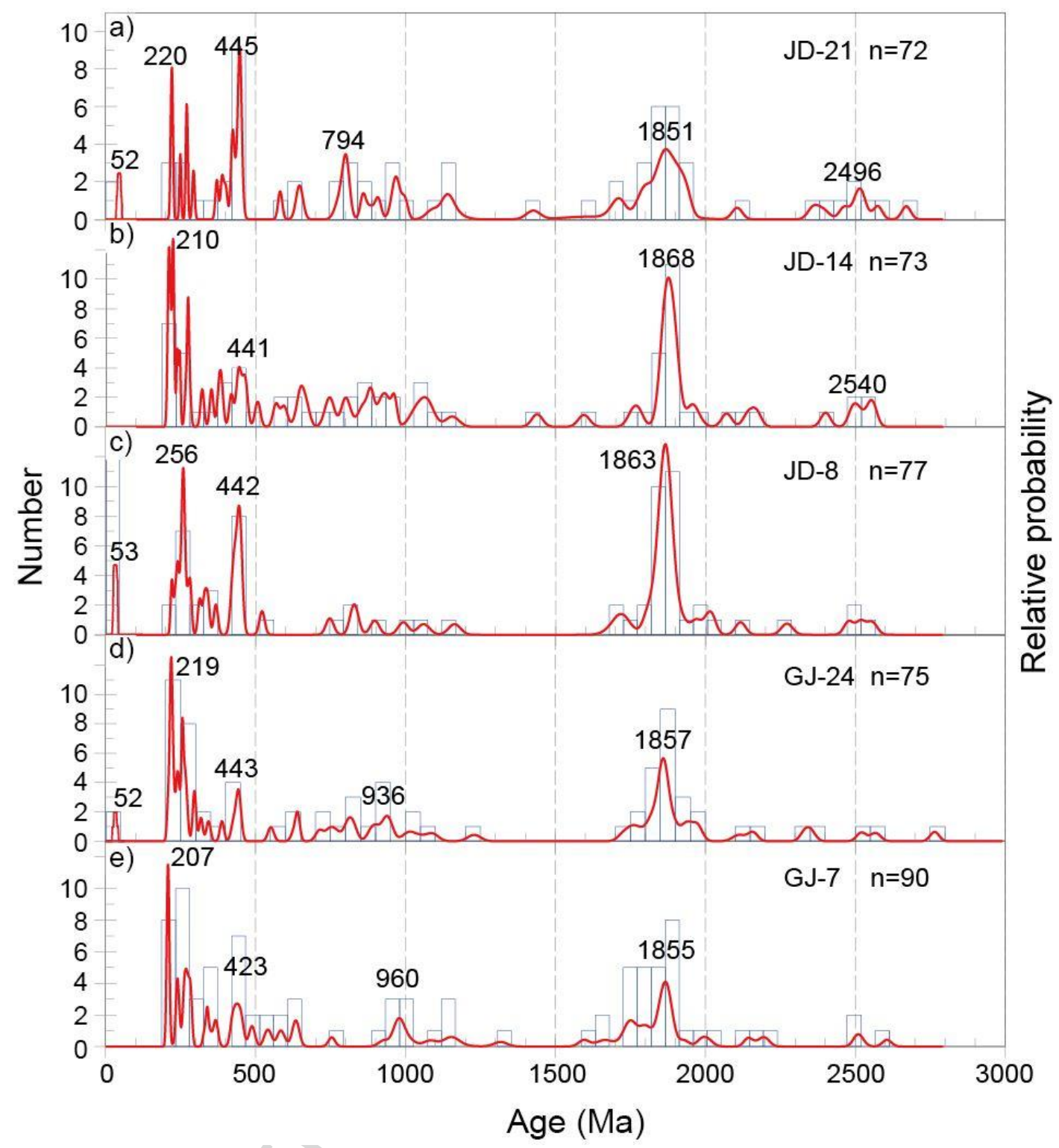

Figure 9. Relative age probability curves of U-Pb analysis on Eocene detrital zircon from the

Gongjue Basin. 


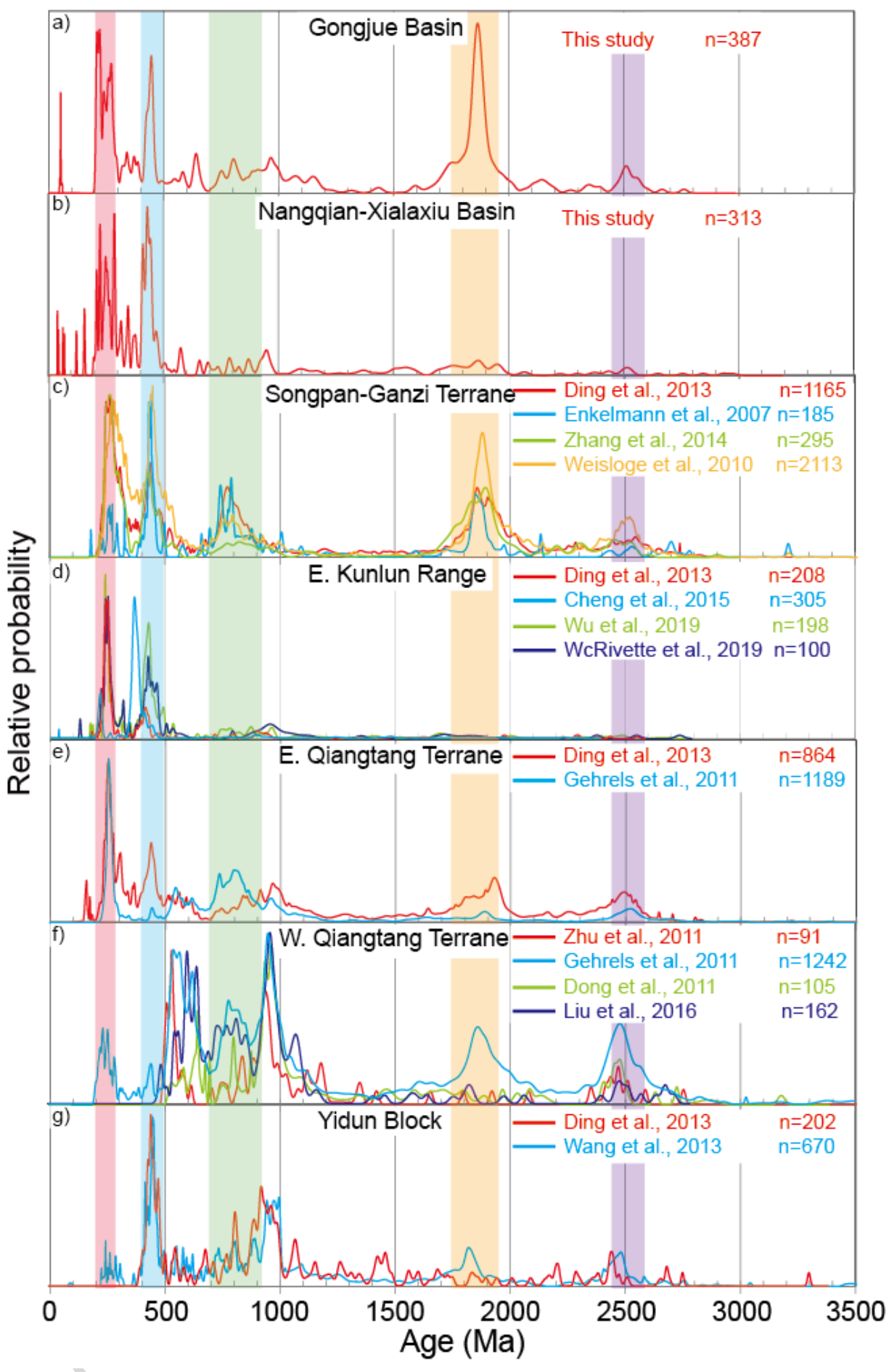

Figure 10. Comparison of detrital zircon U-Pb age probability plots for the Cenozoic sediments from (a-b) the study basins and the pre-Cenozoic sediments from (c) the Songpan-Ganzi Terrane, (d) eastern Qiangtang Terrane, (e) western Qiangtang Terrane, and (f) Yidun Block. Important age peaks are shown in colorful bands. Data details are given in Table S4 in the supplementary material. 


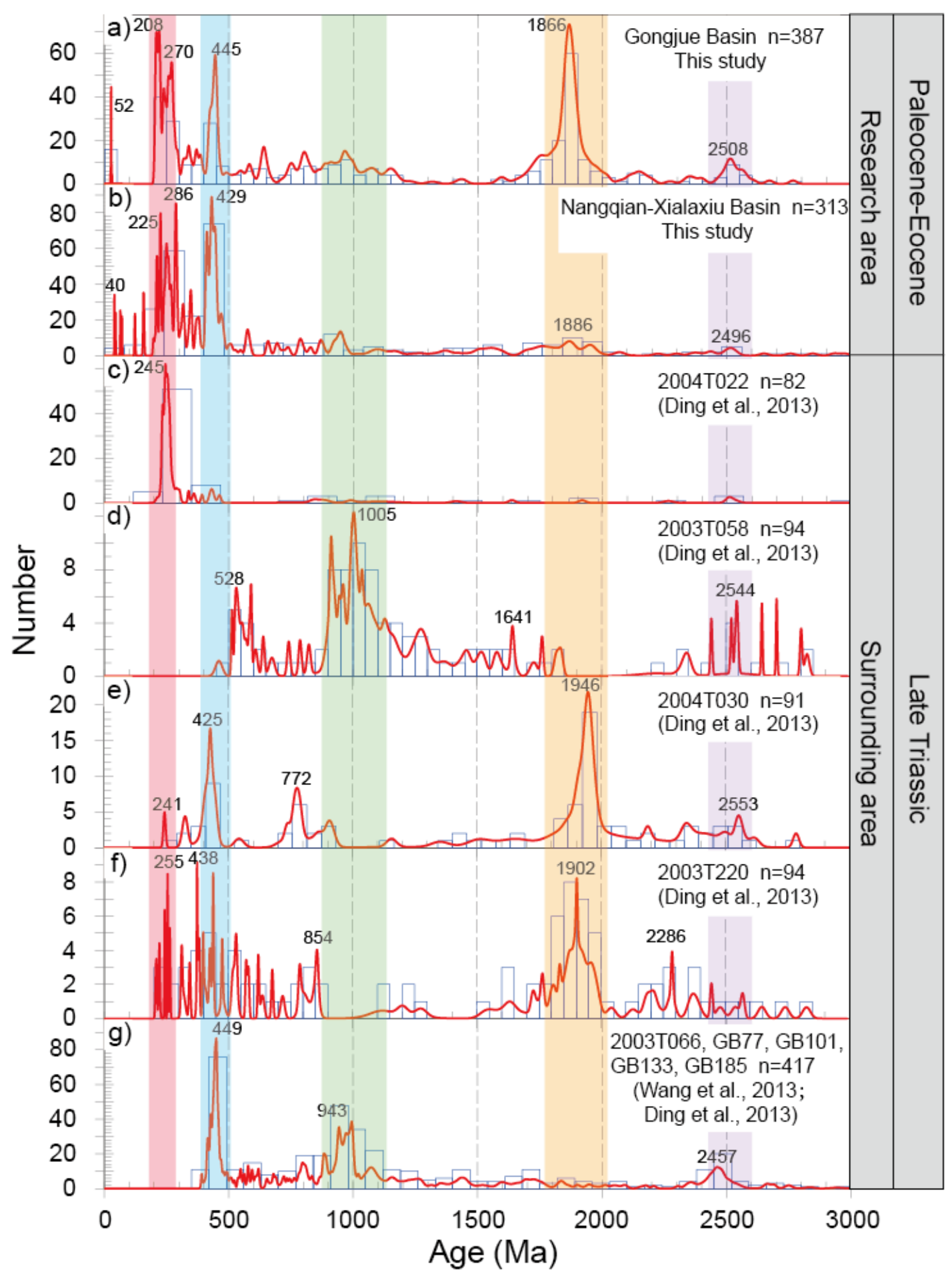

Figure 11. Compilation of detrital zircon U-Pb age distribution patterns of sedimentary rocks from (a-b) this study and (c-g) previous work in the surrounding regions. Important age peaks are shown in colorful bands. Data details are given in Table S4 in the supplementary material. 
a) Stage I: Paleocene time

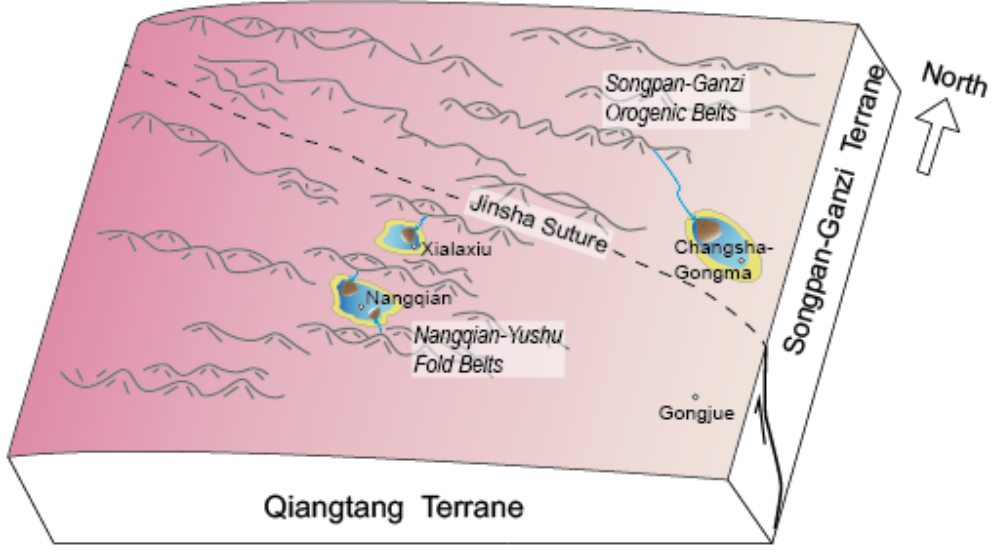

b) Stage II: Eocene time

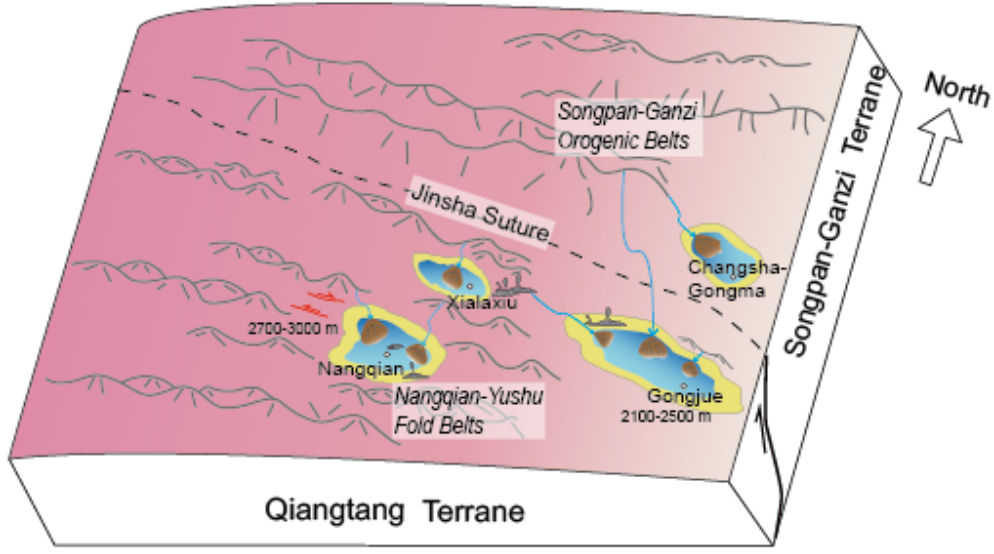

c) Stage III: Oligocene-present

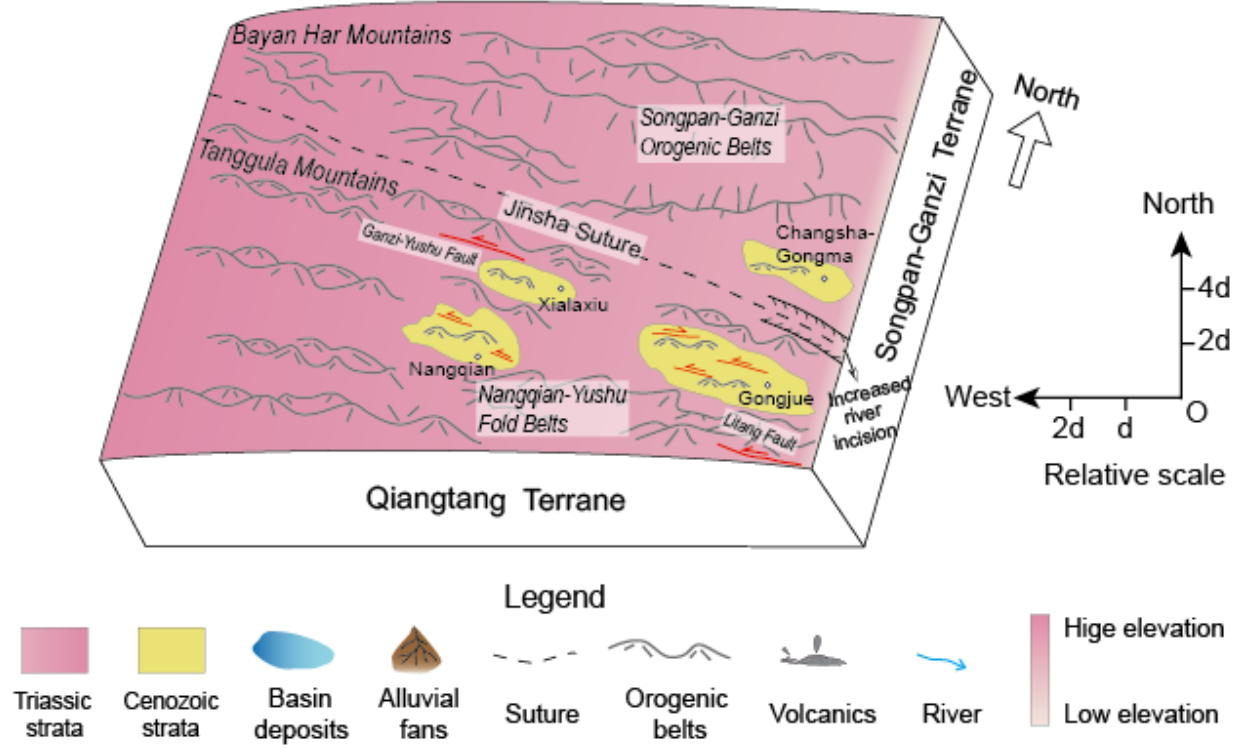

Figure 12. Paleogeographic evolution of the Cenozoic basins in the eastern Tibetan Plateau. See

text for detailed discussions. JS: Jinsha Suture; SGOB: Songpan-Ganzi orogenic belts; GYFB:

Ganzi-Yushu fold belts. For clarity, we only highlight the specific information in detail in the map. 


\section{References}

Allégre, C.J., Courtillot, V., Tapponnier, P., Hirn, A., Coulon, C., Jaeger, J.J., Achache, J., Scharer, U., Marcoux, J.P., Burg, J.P., Girardeau, J., Armijo, R., Gariepy, C., Gopel, C., Li, T.D., Xiao, X. C., Chang, C.F., Li, G.Q., Lin, B.Y., Teng, J.W., Wang, N.W., Chen, G.M., Han, T.L., Wang, X.B., Den, W.M., Sheng, H.B., Cao, Y.G., Zhou, J., Qiu, H.R., Bao, P.S., Wang, S.C., Wang, B.X., Zhou, Y.X., Rong, H.X., 1984. Structure and evolution of the Himalaya-Tibet orogenic belt. Nature 307, 17-22.

Andersen, T., 2002. Correction of common lead in U-Pb analyses that do not report ${ }^{204} \mathrm{~Pb}$. Chemical Geology 192, 59-79.

Bruguier, O., Lancelot, J.R., Malavieille, J., 1997. U-Pb dating on single detrital zircon grains from the Triassic Songpan-Ganze flysch (Central China): provenance and tectonic correlations. Earth and Planetary Science Letters 152, 217-231.

Cheng, F., Fu, S.T., Jolivet, M., Zhang, C.H., Guo, Z.J., 2015. Source to sink relation between the Eastern Kunlun Range and the Qaidam Basin, northern Tibetan Plateau, during the Cenozoic. Geological Society of America Bulletin 128, 1-26.

Clark, M.K., House, M.A., Royden, L.H., Whipple, K.X., Burchfiel, B.C., Tang, W., 2005. Late Cenozoic uplift of southeastern Tibet. Geology 33, 525-528.

Dai, J.G., Li, Y.L., Ge, Y.K., 2013. Detrital zircon U-Pb age and Hf isotopic composition, and detrital apatite (U-Th)/He age from the Paleogene sediments of Changsha-Gongma Basin, the Songpan-Ganzi block and their geological significance (in Chinese with English abstract). Acta Petrologica Sinica 29, 1003-1016.

Dai, J.G., Zhao, X.X., Wang, C.S., Zhu, L.D., Li, Y.L., Finn, D., 2012. The vast proto-Tibetan Plateau: 
New constraints from Paleogene Hoh Xil Basin. Gondwana Research 22, 434-446.

DeCelles, P.G., Kapp, P., Gehrels, G.E., Ding, L., 2014. Paleocene-Eocene foreland basin evolution in the Himalaya of southern Tibet and Nepal: Implications for the age of initial India-Asia collision.

Tectonics 33, 824-849.

Dickinson, W.R., 1985. Interpreting Provenance Relations from Detrital Modes of Sandstones. In: Zuffa, G. G. (Ed.), Provenance of Arenites. NATO Science Series 148, pp. 333-361.

Dickinson, W.R., Beard, L.S., Brakenridge, G.R., Erjavec, J.L., Ferguson, R.C., Inman, K.F., Knepp, R.A., Lindberg, F.A., Ryberg, P.T., 1983. Provenance of North American Phanerozoic sandstones in relation to tectonic setting. Geological Society of America Bulletin 94, 222-235.

Dickinson, W.R., Suczek, C., 1979. Plate tectonics and sandstone compositions. The American Association of Petroleum Geologists Bulletin 63, 2164-2182.

Ding, L., Yang, D., Cai, F.L., Pullen, A., Kapp, P., Gehrels, G.E., Zhang, L.Y., Zhang, Q.H., Lai, Q.Z., Yue, Y.H., Shi, R.D., 2013. Provenance analysis of the Mesozoic Hoh-Xil-Songpan-Ganzi turbidites in northern Tibet: Implications for the tectonic evolution of the eastern Paleo-Tethys Ocean. Tectonics 32, 34-48.

Dong, C.Y., Li, C., Wan, Y.S., Wang, W., Wu, Y.W., Xie, H.Q., Liu, D.Y., 2011. Detrital zircon age model of Ordovician Wenquan quartzite south of Lungmuco-Shuanghu Suture in the Qiangtang area, Tibet: Constraint on tectonic affinity and source regions. Science China: Earth Sciences 54, 1034-1042.

Du, H.F., Jiang, Y.B, Hou, Z.Q., Yan, Z.B., Guo, F.S., Guo, Z.L., 2011a. Geochemical characteristics of Paleogene sandstones in Nangqen basin and their implications for provenance and sedimentary environments (in Chinese with English abstract). Acta Petrologica et Mineralogica 30, 654-664. 
Du, H.F, Zhu, Z.J, Jiang, Y.B., Yang, T.N., Liu, Y.X., Guo F.S., 2011b. Petrological characteristics and provenance analysis of sandstones of Gonjo Formation in Nangqen basin (in Chinese with English abstract). Acta Petrologica et Mineralogica 30, 401-408.

Dupont-Nivet, G., Lippert, P.C., van Hinsbergen, D.J.J., Meijers, M.J.M., Kapp, P., 2010. Palaeolatitude and age of the Indo-Asia collision: palaeomagnetic constraints. Geophysical Journal International 182, 1189-1198.

Duvall, A.R., Clark, M.K., Avdeev, B., Farley, K.A., Chen, Z.W, 2012. Widespread late Cenozoic increase in erosion rates across the interior of eastern Tibet constrained by detrital low-temperature thermochronometry. Tectonics 31, 1-23.

Enkelmann, E., Weislogel, A., Ratschbacher, L., Eide, E., Renno, A., Wooden, J., 2007. How was the Triassic Songpan-Ganzi basin filled? A provenance study. Tectonics 26, 1-24.

Fan, J.J., Li, C., Wang, M., Xie, C.M., Xu, W., 2015. Features, provenance, and tectonic significance of Carboniferous-Permian glacial marine diamictites in the Southern Qiangtang-Baoshan block, Tibetan Plateau. Gondwana Research 28, 1530-1542.

Fielding, E.J., 1996. Tibet uplift and erosion. Tectonophysics 260(1-3), 55-84.

Gehrels, G., Kapp, P., DeCelles, P., Pullen, A., Blakey, R., Weislogel, A., Ding, L., Guynn, J., Martin, A., McQuarrie, N., Yin, A., 2011. Detrital zircon geochronology of pre-Tertiary strata in the Tibetan-Himalayan orogen. Tectonics 30,1-27.

Gehrels, G.E., Yin, A., Wang, X.F., 2003. Detrital-zircon geochronology of the northeastern Tibetan plateau. Geological Society of America Bulletin 115, 881-896.

Harrowfield, M.J., Wilson, C.J.L., 2005. Indosinian deformation of the Songpan Garzê Fold Belt, northeast Tibetan Plateau. Journal of Structural Geology 27, 101-117. 
Horton, B.K., Yin, A., Spurlin, M.S., Zhou, J.Y., Wang, J.H., 2002. Paleocene-Eocene syncontractional sedimentation in narrow, lacustrine-dominated basins of east-central Tibet. Geological Society of America Bulletin 114, 771-786.

Hu, X.M., Wang, J.G., BouDagher-Fadel, M., Garzanti, E. An, W., 2016. New insights into the timing of the India-Asia collision from the Paleogene Quxia and Jialazi formations of the Xigaze forearc basin, South Tibet. Gondwana Research 32, 76-92.

Huang, W.T., van Hinsbergen, D.J.J., Lippert, P.C., Guo, Z.J. Dupont-Nivet, G., 2015. Paleomagnetic tests of tectonic reconstructions of the India-Asia collision zone. Geophysical Research Letters 42, 2642-2649.

Ingersoll, R.V., Bullard, T.F., Ford, R.L., Grimm, J.P., Pickle, J.D. Sares, S.W., 1984. The effect of grain size on detrital modes: a test of the Gazzi-Dickinson point-counting method. Journal of Sedimentary Petrology 54, 103-106.

Jackson, S.E., Pearson, N.J., Griffin, W.L., Belousova, E.A., 2004. The application of laser ablation-inductively coupled plasma-mass spectrometry to in situ U-Pb zircon geochronology. Chemical Geology 211, 47-69.

Jiang, Y.B., Guo, F.S., Hou, Z.Q., Yang, T.N., Liu, Y.X., Yang, Q.K., Du, H.F., 2011. Sedimentary features and evolution of the Nangqen Paleogene basin in northeastern Qinghai-Tibet Plateau (in Chinese with English abstract). Acta Petrologica et Mineralogica 30, 391-400.

Jiang, Y.B., Hou, Z.Q., Yan, Z.B., Du, H.F., Guo, F.S., Liu, Y.X., 2009. Prototype and Evolution of the Tertiary Basins in Yushu Area, Qinghai (in Chinese with English abstract). Geotectonica et Metallogenia 33, 520-528.

Kapp, P., Yin, A., Harrison, T.M., Ding, L., 2005. Cretaceous-Tertiary shortening, basin development, 
and volcanism in central Tibet. Geological Society of America Bulletin 117, 865-878.

Kapp. P., Murphy, M.A., Yin, A., Harrison, T.M., Ding, L., Guo, J.H., 2003a. Mesozoic and Cenozoic tectonic evolution of the Shiquanhe area of western Tibet. Tectonics 22, 1-24.

Kapp, P., Yin, A., Manning, C.E., Harrison, T.M., Taylor, M.H., Ding, L., 2003b. Tectonic evolution of the early Mesozoic blueschist-bearing Qiangtang metamorphic belt, central Tibet. Tectonics 22, $1-25$.

Kapp, P., Yin, A., Manning, C.E., Murphy, M., Harrison, T.M., Spurlin, M., Ding, L., Deng, X.G., Wu, C.M., 2000. Blueschist-bearing metamorphic core complexes in the Qiangtang block reveal deep crustal structure of northern Tibet. Geology 28, 19-22.

Kornfeld, D., Eckert, S., Appel, E., Ratschbacher, L., Pfänder, J.A., Liu, D.L., Ding, L., 2014. Clockwise rotation of the Baoshan Block due to southeastward tectonic escape of Tibetan crust since the Oligocene. Geophysical Journal International 197, 149-163.

Kornfeld, D., Eckert, S., Appel, E., Ratschbacher, L., Sonntag, B. L., Pfänder, J. A., Ding, L., Liu, D.L., 2014. Cenozoic clockwise rotation of the Tengchong block, southeastern Tibetan Plateau: A paleomagnetic and geochronologic study. Tectonophysics 628, 105-122.

Li, C., Zhai, M.G., Dong, Y.S., Liu, S., Xie, C.M., Wu, Y.W., 2009. High-Pressure Eclogite-Blueschist Metamorphic Belt and Closure of Paleo-Tethys Ocean in Central Qiangtang, Qinghai-Tibet Plateau. Journal of Earth Science 20, 209-218.

Li, D.P., Chen, Y.L., Hou, K.J., Lu, Z., Cui, D., 2015a. Detrital zircon record of Paleozoic and Mesozoic meta-sedimentary strata in the eastern part of the Baoshan block: Implications of their provenance and the tectonic evolution of the southeastern margin of the Tibetan plateau. Lithos 227, 194-204. 
Li, L., Fan, M.J., Davila, N., Jesmok, G., Mitsunaga, B., Tripati, A., Orme, D., 2018a. Carbonate stable and clumped isotopic evidence for late Eocene moderate to high elevation of the east-central Tibetan Plateau and its geodynamic implications. Geological Society of America Bulletin 131, $831-844$

Li, L., Wu, C.D., Yu, X.J., 2018b. Cenozoic evolution of the Altyn Tagh and East Kunlun fault zones inferred from detrital garnet, tourmaline and rutile in southwestern Qaidam Basin (Northern Tibetan Plateau). Basin Research, 30, 35-58.

Li, S.H., Advokaat, E.L., van Hinsbergen, D.J.J., Koymans, M., Deng, C.L., Zhu, R.X., 2017. Paleomagnetic constraints on the Mesozoic-Cenozoic paleolatitudinal and rotational history of Indochina and South China: Review and updated kinematic reconstruction. Earth-Science Reviews 171, 58-77.

Li, S.Y., Currie, B.S., Rowley, D.B., Ingalls, M., 2015b. Cenozoic paleoaltimetry of the SE margin of the Tibetan Plateau: Constraints on the tectonic evolution of the region. Earth and Planetary Science Letters 432, 415-424.

Li, Y.L., Wang, C.S., Zhao, X.X., Yin, A., Ma, C., 2012. Cenozoic thrust system, basin evolution, and uplift of the Tanggula Range in the Tuotuohe region, central Tibet. Gondwana Research 22, $482-492$.

Liu, Y.M., Li, C., Xie, C.M., Fan, J.J., Wu, H., 2016. Detrital zircon U-Pb ages and Hf isotopic composition of the Ordovician Duguer quartz schist, central Tibetan Plateau: constraints on tectonic affinity and sedimentary source regions. Geological Magazine 154, 558-570.

Ludwig, K. R., 2003. User's manual for Isoplot 3.0: a geochronological toolkit for Microsoft Excel. Berkeley Geochronology Center Special Publication 4, 1-71. 
Ma, Y.M., Yang, T.S., Yang, Z.Y., Zhang, S.H., Wu, H.C, Li, H.Y., Li, H.K., Chen, W.W., Zhang, J.H.,

Ding, J.K., 2014. Paleomagnetism and U-Pb zircon geochronology of Lower Cretaceous lava flows from the western Lhasa terrane: New constraints on the India-Asia collision process and intracontinental deformation within Asia. Journal of Geophysical Research: Solid Earth 119, $7404-7424$.

Manzotti, P., Poujol, M., Ballèvre, M., 2015. Detrital zircon geochronology in blueschist-facies meta-conglomerates from the Western Alps: implications for the late Carboniferous to early Permian palaeogeography. International Journal of Earth Science 104, 703-731.

McRivette, M.W., Yin, A., Chen, X.H., Gehrels, G.E., 2019. Cenozoic basin evolution of the central Tibetan plateau as constrained by U-Pb detrital zircon geochronology, sandstone petrology, and fission-track thermochronology. Tectonophysics 751, 150-179.

Metcalfe, I., 2013. Gondwana dispersion and Asian accretion: Tectonic and palaeogeographic evolution of eastern Tethys. Journal of Asian Earth Sciences 66, 1-33.

Najman, Y., 2005. The detrital record of orogenesis: A review of approaches and techniques used in the Himalayan sedimentary basins. Earth-Science Reviews 74, 1-72.

Otofuji, Y., Mu, C.L., Tanaka, K., Miura, D., Inokuchi, H., Kamei, R., Tamai, M., Takemoto, K., Zaman, H., Yokoyama, M., 2007. Spatial gap between Lhasa and Qiangtang blocks inferred from Middle Jurassic to Cretaceous paleomagnetic data. Earth and Planetary Science Letters 262, $581-593$.

Peng, T.P., Zhao, G.C., Fan, W.M., Peng, B.X., Mao, Y.S., 2014. Zircon geochronology and Hf isotopes of Mesozoic intrusive rocks from the Yidun terrane, Eastern Tibetan Plateau: Petrogenesis and their bearings with $\mathrm{Cu}$ mineralization. Journal of Asian Earth Sciences 80, 
18-33.

Polissar, P.J., Freeman, K.H., Rowley, D.B., McOnerney, F.A., Currie, B.S., 2009. Paleoaltimetry of the Tibetan cPlateau from D/H ratios of lipid biomarkers. Earth and Planetary Science Letters 287, 64-76.

Pullen, A., Kapp, P., Gehrels, G.E., Vervoort, J.D., Ding, L., 2008. Triassic continental subduction in central Tibet and Mediterranean-style closure of the Paleo-Tethys Ocean. Geology 36, 351-354.

Pullen, A., Kapp, P., Gehrels, G.E., Ding, L., Zhang, Q.H., 2011. Metamorphic rocks in central Tibet: Lateral variations and implications for crustal structure. Geological Society of America Bulletin $123,585-600$.

Qinghai BGMR (Bureau of Geology and Mineral Resources of Qinghai Province), 1991. Regional geology of Qinghai Province. Geological Memoirs Series. Beijing: Geological House.

Roger, F., Arnaud, N., Gilder, S., Tapponnier, P., Jolivet, M., Brunel, M., Malavieille, J., Xu, Z.Q., Yang, J.S., 2003. Geochronological and geochemical constraints on Mesozoic suturing in east central Tibet. Tectonics 22, 1-20.

Roger, F., Jolivet, M., Cattin, R., Malavieille, J., 2011. Mesozoic-Cenozoic tectonothermal evolution of the eastern part of the Tibetan Plateau (Songpan-Garzê, Longmen Shan area): insights from thermochronological data and simple thermal modelling. Geological Society, London, Special Publications 353, 9-25.

Roger, F., Jolivet, M., Malavieille, J., 2010. The tectonic evolution of the Songpan-Garzê (North Tibet) and adjacent areas from Proterozoic to Present: A synthesis. Journal of Asian Earth Sciences 39, $254-269$.

Roger, F., Tapponnier, P., Arnaud, N., Schärer, U., Brunel, M., Xu, Z.Q., Yang, J.S., 2000. An Eocene 
magmatic belt across central Tibet: mantle subduction triggered by the Indian collision? Terra Nova 12, 102-108.

Rohrmann, A., Kapp, P., Carrapa, B., Reiners, P.W., Guynn, J., Ding, L., Heizler, M., 2012. Thermochronologic evidence for plateau formation in central Tibet by 45 Ma. Geology 40, 187-190.

Roperch, P., Dupont-Nivet, G., Guillot, S., Goussin, F., Huang, W.T., Replumaz, A., Zhang, Y., Guo, Z.J., Song, B.W., 2017. Paleomagnetic constraints on early collisional deformation along the eastern margin of the Qiantang terrane (Tibetan plateau) at 50 and 37 Ma. Paper presented at EGU General Assembly Conference Abstracts, p. 9476.

Sengör, A.M.C., Natal'In, B.A., 1996. Paleotectonics of Asia: Fragments of a syn thesis. In Yin, A. and Harrison, T. M. (Eds), The Tectonic Evolution of Asia (pp. 486-640). Cambridge University Press.

Sláma, J., Košler, J., Condon, D.J., Crowley, J.L., Gerdes, A., Hanchar, J.M, Horstwood, M.S.A., Morris, G.A., Nasdala, L., Norberg, N., Schaltegger, U., Schoene, B., Tubrett, M.N., Whitehouse, M.J., 2008. Plešovice zircon-A new natural reference material for $\mathrm{U}-\mathrm{Pb}$ and $\mathrm{Hf}$ isotopic microanalysisrlin. Chemical Geology 249, 1-35.

Spurlin, M.S., Yin, A., Horton, B.K., Zhou, J.Y., Wang, J.H., 2005. Structural evolution of the Yushu-Nangqian region and its relationship to syncollisional igneous activity, east-central Tibet. Geological Society of America Bulletin 117, 1293-1317.

Staisch, L.M., Niemi, N.A., Clark, M.K., Chang, H., 2016. Eocene to late Oligocene history of crustal shortening within the Hoh Xil Basin and implications for the uplift history of the northern Tibetan Plateau. Tectonics 35, 862-895. 
Studnicki-Gizbert, C., Burchfiel, B.C., Li, Z., Chen, Z., 2008. Early Tertiary Gonjo basin, eastern Tibet: Sedimentary and structural record of the early history of India-Asia collision. Geosphere 4, 713-735.

Tang, M.Y., Zeng, J.L., Hoke, G.D., Xu, Q., Wang, W.T., Li, Z.F., Zhang, J.Y., Wang, W., 2017. Paleoelevation reconstruction of the Paleocene-Eocene Gonjo basin, SE-central Tibet. Tectonophysics 712-713, 170-181.

Tapponnier, P., Xu, Z.Q., Roger, F., Meyer, B., Arnaud, N., Wittlinger, G., Yang, J.S., 2001. Oblique Stepwise Rise and Growth of the Tibet Plateau. Science 294, 1671-1677.

Tibet BGMR (Bureau of Geology and Mineral Resources of Xizang Autonomous Region), 1993. Regional geology of Xizang (Tibet) Autonomous Region. Geological Memoirs Series (Vol. 1, Number 31, p. 707). Beijing: Geological House.

Tong, Y.B., Yang, Z.Y., Gao, L., Wang, H., Zhang, X.D., An, C.Z., Xu, Y.C., Han, Z.R., 2015. Paleomagnetism of Upper Cretaceous red-beds from the eastern Qiangtang Block: Clockwise rotations and latitudinal translation during the India-Asia collision. Journal of Asian Earth Sciences 114, 732-749.

Tong, Y.B., Yang, Z.Y., Mao, C.P., Pei, J.P., Pu, Z.W., Xu, Y.C., 2017. Paleomagnetism of Eocene red-beds in the eastern part of the Qiangtang Terrane and its implications for uplift and southward crustal extrusion in the southeastern edge of the Tibetan Plateau. Earth and Planetary Science Letters $475,1-14$.

Wang, B.Q, Wang, W., Chen, W.T., Gao, J.F., Zhao, X.F., Yan, D.P., 2013. Constraints of detrital zircon $\mathrm{U}-\mathrm{Pb}$ ages and $\mathrm{Hf}$ isotopes on the provenance of the Triassic Yidun Group and tectonic evolution of the Yidun Terrane, Eastern Tibet. Sedimentary Geology 289, 74-98. 
Wang, C.S., Dai, J.G., Zhao, X.X., Li, Y.L., Graham, S.A., He, D.F., Ran, B., Meng, J., 2014. Outward-growth of the Tibetan Plateau during the Cenozoic: A review. Tectonophysics 621, 1-43.

Wang, C.S., Zhao, X.X., Liu, Z.F., Lippert, P.C., Graham, S.A., Coe, R.S., Yi, H.S., Zhu, L.D., Liu, S., Li, Y.L., 2008. Constraints on the early uplift history of the Tibetan Plateau. Proceedings of the National Academy of Science of the United States of America 105, 4987-4992.

Wang, J.H., Yin, A., Harrison, T.M., Grove, M., Zhang, Y.Q., Xie, G.H., 2001a. A tectonic model for Cenozoic igneous activities in the eastern Indo-Asian collision zone. Earth and Planetary Science Letters 188, 123-133.

Wang, S.F., Yi, H.S., Wang, C.S., 2001b. Sedimentary facies and palaeogeography features of Nangqian Tertiary basin in Yushu district, Qinghai (in Chinese with English abstract). Northwestern Geology 34, 64-67.

Wang, S.F., Yi, H.S., Wang, C.S., 2002. Sediments and Structural Features of Nangqian Tertiary Basin in Eastern of Tibet- Qingzang Plateau (in Chinese with English abstract). Acta Scientiarum Naturalium, Universitatis Pekinensis 38, 109-114.

Wang, Z.W., Wang, J., Fu, X.G., Feng, X.L., Wang, D., Song, C.Y., Chen, W.B., Zeng, S.Q., Yu, F., 2017. Provenance and tectonic setting of the Quemoco sandstones in the North Qiangtang Basin, North Tibet: Evidence from geochemistry and detrital zircon geochronology. Geological Journal 53, 1-17.

Weislogel, A.L., Graham, S.A., Chang, E.Z., Wooden, J.L., Gehrels, G.E., 2010. Detrital zircon provenance from three turbidite depocenters of the Middle-Upper Triassic Songpan-Ganzi complex, central China: Record of collisional tectonics, erosional exhumation, and sediment production. Geological Society of America Bulletin 122, 2041-2062. 
Weislogel, A.L., Graham, S.A., Chang, E.Z., Wooden, J.L., Gehrels, G.E., Yang, H.S., 2006. Detrital zircon provenance of the Late Triassic Songpan-Ganzi complex: Sedimentary record of collision of the North and South China blocks. Geology 34, 97-100.

Wiedenbeck, M., Allé, P., Corfu, F., Griffin, W.L., Meier, M., Oberli, F., Quadt, A.V., Roddick, J.C., Spiegel, W., 1995. Three natural zircon standards for U-Th-Pb, Lu-Hf, trace element and REE analyses. Geostandards Newsletter 19, 1-23.

Wu, C., Zuza, A.V., Chen, X.H., Ding, L., Levy, D.A., Liu, C.F., Liu, W.C., Jiang, T., Stockli, D.F., 2019a. Tectonics of the Eastern Kunlun Range: Cenozoic Reactivation of a Paleozoic-Early Mesozoic Orogen. Tectonics. doi.org/10.1029/2018TC005370.

Wu, C., Zuza, A.V., Zhou, Z.G., Yin, A., McRivette, M.W., Chen, X.H., Ding, L., Geng, J.Z., $2019 b$. Mesozoic-Cenozoic evolution of the Eastern Kunlun Range, central Tibet, and implications for basin evolution during the Indo-Asian collision. Lithosphere. doi.org/10.1130/L1065.1.

Wu, F.Y., Ji, W.Q., Liu, C.Z., Chung, S.L., 2010. Detrital zircon U-Pb and Hf isotopic data from the Xigaze fore-arc basin: Constraints on Transhimalayan magmatic evolution in southern Tibet. Chemical Geology 271, 13-25.

Wu, T., Xiao, L., Ma, C.Q., 2016. U-Pb geochronology of detrital and inherited zircons in the Yidun arc belt, eastern Tibet Plateau and its tectonic implications. Journal of Earth Science 27, 461-473.

Xu, L.L., Bi, X.W., Hu, H.R., Qi, Y.Q., Tang, Y.Y., Wang, X.S., Zhu, J.J., 2016. Redox states and genesis of magmas associated with intra-continental porphyry $\mathrm{Cu}-\mathrm{Au}$ mineralization within the Jinshajiang-Red River alkaline igneous belt, SW China. Ore Geology Reviews 73, 330-345.

Xu, Y., Bi, X.W., Hu, R.Z., Chen, Y.W., Liu, H.Q, Xu, L.L., 2016. Geochronology and Geochemistry of Eocene Potassic Felsic Intrusions in the Nangqian Basin, Eastern Tibet: Tectonic and 
Metallogenic Implications. Lithos 246-247, 212-227.

Yang, T.N., Hou, Z.Q., Wang, Y., Zhang, H.R., Wang, Z.L., 2012. Late Paleozoic to Early Mesozoic tectonic evolution of northeast Tibet: Evidence from the Triassic composite Western Jinsha-Garzê-Litang suture. Tectonics 31, 1-20.

Yang, W., Jolivet, M., Dupont-Nivet, G., Guo, Z.J., 2014. Mesozoic-Cenozoic tectonic evolution of southwestern Tian Shan: Evidence from detrital zircon $\mathrm{U} / \mathrm{Pb}$ and apatite fission track ages of the Ulugqat area, Northwest China. Gondwana Research 26, 986-1008.

Yi, H.S., Wang, C.S., Shi, Z.Q., Lin, J.H., Zhu, L.D., 2008. Early Uplift History of the Tibetan Plateau: Records from Paleocurrents and Paleodrainage in the Hoh Xil Basin. Acta Geologica Sinica 82, 206-213.

Yin, A., and Harrison, T.M., 2000. Geologic Evolution of the Himalayan-Tibetan Orogen. Annual Review of Earth and Planetary Sciences 28, 211-280.

Yu, X.J., Huang, B.C., Guan, S.W., Fu, S.T., Cheng, F., Cheng, X., Zhang, T., Guo, Z.J., 2014. Anisotropy of magnetic susceptibility of Eocene and Miocene sediments in the Qaidam basin, northwest china: implication for Cenozoic tectonic transition and depocenter migration. Geochemistry, Geophysics, Geosystems 15, 2095-2108.

Yu, X.J., Guo, Z.J., Zhang, Q.Q., Cheng, X., Du, W., Wang, Z.D., Bian, Q. 2017. Denan depression controlled by northeast-directed Olongbulak thrust zone in northeastern Qaidam basin: implications for growth of northern Tibetan Plateau. Tectonophysics 717, 116-126.

Yuan, D.Y., Ge, W.P., Chen, Z.W., Li, C.Y., Wang, Z.C., Zhang, H.P., 2013. The growth of northeastern Tibet and its relevance to large-scale continental geodynamics: A review of recent studies. Tectonics 32, 1358-1370. 
Zhai, Q.G., Jahn, B.M., Zhang, R.Y., Wang, J., Su, L., 2011a. Triassic Subduction of the Paleo-Tethys in northern Tibet, China: Evidence from the geochemical and isotopic characteristics of eclogites and blueschists of the Qiangtang Block. Journal of Asian Earth Sciences 42, 1356-1370.

Zhai, Q.G., Zhang, R.Y., Jahn, B.M., Li, C., Song, S.G., Wang, J., 2011b. Triassic eclogites from central Qiangtang, northern Tibet, China: Petrology, geochronology and metamorphic P-T path. Lithos 125, 173-189.

Zhang, K.J., Cai, J.X., Zhang, Y.X., Zhao, T.P., 2006a. Eclogites from central Qiangtang, northern Tibet (China) and tectonic implications. Earth and Planetary Science Letters 245, 722-729.

Zhang, K.J., Zhang, Y.X., Li, B., Zhu, Y.T., Wei, R.Z., 2006b. The blueschist-bearing Qiangtang metamorphic belt (northern Tibet, China) as an in situ suture zone: Evidence from geochemical comparison with the Jinsa suture. Geology 34, 493-496.

Zhang, K.X., Wang, G.C., Hong, H.L., Xu, Y.D., Wang, A., Cao, K., Luo, M.S., Ji, J.L., Xiao, G.Q., Lin, X., 2013. The study of the Cenozoic uplift in the Tibetan Plateau: A review (in Chinese with English abstract). Geological Bulletin of China 32, 1-18.

Zhang, Y., Huang, W. T., Huang, B. C., van Hinsbergen, D. J. J., Yang, T., Dupont-Nivet, G., Guo, Z.J., 2018. 53-43 Ma Deformation of Eastern Tibet Revealed by Three Stages of Tectonic Rotation in the Gongjue Basin. Journal of Geophysical Research: Solid Earth 123, 3320-3338.

Zhang, Y.X., Tang, X.C., Zhang, K.J., Zeng, L., Gao, C.L., 2014. U-Pb and Lu-Hf isotope systematics of detrital zircons from the Songpan-Ganzi Triassic flysch, NE Tibetan Plateau: implications for provenance and crustal growth. International Geology Review 56, 29-56.

Zhou, J.Y., Wang, J.H., Yin, A., Spurlin, M.S., Horton, B.K., 2002. Depositional Patterns and Tectonic Setting of Early Tertiary Basins in the NE Margin of the Tibetan Plateau: A Case Study of the 
Nangqian and Xialaxiu Basins (in Chinese with English abstract). Acta Sedimentologica Sinica 20, 85-91.

Zhu, D.C., Zhao, Z.D., Niu, Y.L., Dilek, Y., Mo, X.X., 2011. Lhasa terrane in southern Tibet came from Australia. Geology 39, 727-730.

Zhu, D.C., Zhao, Z.D., Niu, Y.L., Dilek, Y., Hou, Z.Q., Mo, X.X., 2013. The origin and pre-Cenozoic evolution of the Tibetan Plateau. Gondwana Research 23, 1429-1454.

Zhu, L., Zhang, H.H., Wang, J.H., Zhou, J.Y., Jie, G.H., 2006a. ${ }^{40} \mathrm{Ar} /{ }^{39} \mathrm{Ar}$ chronology of high-K magmatic rocks in Nangqian basins at the northern segment of the Jinsha-Red river shear zone (in Chinese with English abstract). Geotectonica et Metallogenia 32, 241-247.

Zhu, L.D., Wang, C.S., Zheng, H.B., Xiang, F., Yi, H.S., Liu, D.Z., 2006b. Tectonic and sedimentary evolution of basins in the northeast of Qinghai-Tibet Plateau and their implication for the northward growth of the Plateau. Palaeogeography, Palaeoclimatology, Palaeoecology 241, 49-60. 


\section{Highlights:}

1. Detrital zircon U-Pb ages of the sediments from two basins are distinguishable.

2. The sediments in Nangqian-Xialaxiu Basin are issued from neighboring mountains.

3. The sediments in Gongjue Basin are mainly from the Songpan-Ganzi Terrane.

4. A three-stage paleogeographic evolution of the eastern Tibet can be proposed. 